\title{
Fieldwork in northern Viti Levu and Mago Island
}

\author{
Geoffrey Clark \\ Archaeology and Natural History, The Australian National University \\ Atholl Anderson \\ Archaeology and Natural History, The Australian National University
}

\section{Introduction}

This chapter outlines fieldwork in north Viti Levu and on Mago Island in the Lau Group. Major investigations were made at two already known north-coast Viti Levu sites: the Lapita site of Natunuku, in Ba Province, and Navatu 17A, in Rakiraki Province. On Mago Island, a Lapita site at Votua was discovered and excavated in 1997 and 2000. A rock shelter known as Sovanibeka, inland from the Votua site, was also briefly examined. The research history and fieldwork involving these sites in our project is described below.

The north coast of Viti Levu is predominantly volcanic and, being on the leeward side, coastal zones have both a relatively low rainfall $(<1800 \mathrm{~mm}$ per annum) and a propensity to drought. The highland core of Viti Levu exerts a powerful orographic effect on the southeast trade winds and the north coast experiences marked rain shadow in both wet and dry seasons relative to southern Viti Levu. The difficult environmental conditions were alleviated in prehistory by the construction of numerous fish traps (moka) on the coast and offshore islands and extensive irrigated terracing, particularly on the flanks and flood plains of the Nakauvadra Range (Kuhlken and Crosby 1999). Nonetheless, the lower economic productivity of the north coast is suggested by Parry (1997:147) to be manifested in the absence of very large sites and the lack of a site hierarchy in his aerial-photo site analysis, indicating general equality of status and the existence of a simple prehistoric polity compared with the large and complex socio-political entities that developed in southern and southeastern Viti Levu (Parry 1987). 
Gifford's (1951) archaeological reconnaissance turned up 12 coastal sites between Lautoka and Rakiraki. One was Navatu 17A, which became the type site for the Navatu phase proposed by Green (1963), lasting from about 2100 to 900 BP. An older site, Natunuku (VL 1/1), found in 1967, contained Lapita pottery with early decorative styles. Both sites have been important in constructing and revising the first half of the archaeological sequence of Fiji (Green 1963; Best 1984, 2002; Clark and Murray 2006). Our aim was to locate previous excavations and obtain new sets of cultural remains, as the antiquity, nature and context of prehistoric materials at both sites was unclear, despite previous analyses of excavated material and reinterpretation of the deposits (Green 1963; Shaw 1967; Davidson et al. 1990; Davidson and Leach 1993). In short, archaeological uncertainty regarding the Natunuku and Navatu 17A sites has fed through to the entire Fiji sequence, hindering debate on the age of human colonisation in Fiji (e.g. Kirch and Hunt 1988; Spriggs 1990) and preventing a close comparison of ceramics and other artefacts, necessary to evaluate the extent of cultural variation within the archipelago and potential linkages between Fiji and other islands (Wahome 1995; Burley 2005).

A second project on Mago Island was centred on a late-Lapita site found in 1996 during a joint USP-Fiji Museum-ANU survey of archaeological deposits coordinated by Professor Patrick Nunn (Geography Department, USP). Some linguistic and archaeological data points to an early cultural divide between west Fiji and east Fiji (Geraghty 1983; Best 1984), which may have occurred as a result of Lapita groups from Tonga colonising parts of the Lau Group (Best 1984; Clark and Murray 2006). The issue of significant variation in the intra-archipelagic rate of prehistoric colonisation is one that could be tested by a comparison of Votua ceramics with pottery of late-Lapita age in west Fiji (i.e. Sigatoka, Level 1) and Tonga. During investigations at Votua, the small shelter of Sovanibeka was investigated and a few ceramics of Lapita and midsequence antiquity were recovered.

\section{Fieldwork at Natunuku, VL 1/1}

Natunuku is the name of a village and its immediate district near the mouth of the Ba River (Figure 60). A low peninsula of Pliocene volcanics projects westward for $1 \mathrm{~km}$ towards the river mouth from the northerly trending coastline. On the north side of the peninsula, facing a shallow, muddy estuary that merges into the broad northern lagoon of Viti Levu, is situated site VL 1/1. The existence of a Lapita site there was first evident to Bruce Palmer, Director of the Fiji Museum, in the mid 1960s when he saw sherds from the beach front, then actively eroding, and collected by Peter Bean. A rescue excavation was carried out by Elizabeth Shaw and Moce Qalo in August-September 1967, as part of a two-year program on Fijian archaeology, 1965-1967, funded by the National Science Foundation. Palmer (1968:24), writing during the period of excavation, observed that the Lapita-style pottery was more profusely decorated than at Sigatoka and probably earlier, making it, at that time, the oldest site in Fiji. This proposition was strengthened by an initial radiocarbon date from Layer 6, the basal cultural level, of 3240 \pm 100 BP (GaK-1218), and subsequent analyses of the Lapita assemblage, notably by Mead et al. (1973), led to the conclusion that at least part belonged to Green's (1974) Early Eastern Lapita Phase.

Subsequent research on the Natunuku pottery assemblage from Location C, where Lapita ceramics had been prominent, by Davidson et al. (1990), showed that while dentate-stamped Lapita wares were concentrated proportionately in the basal layer, they also occurred throughout the Natunuku stratigraphy and thus within ceramic contexts that spanned the full Fijian prehistoric sequence. In fact, the largest number and weight of dentate-stamped, unshaped body sherds at Location $\mathrm{C}$ occurred very near the surface, in Layer 3, together with the highest 


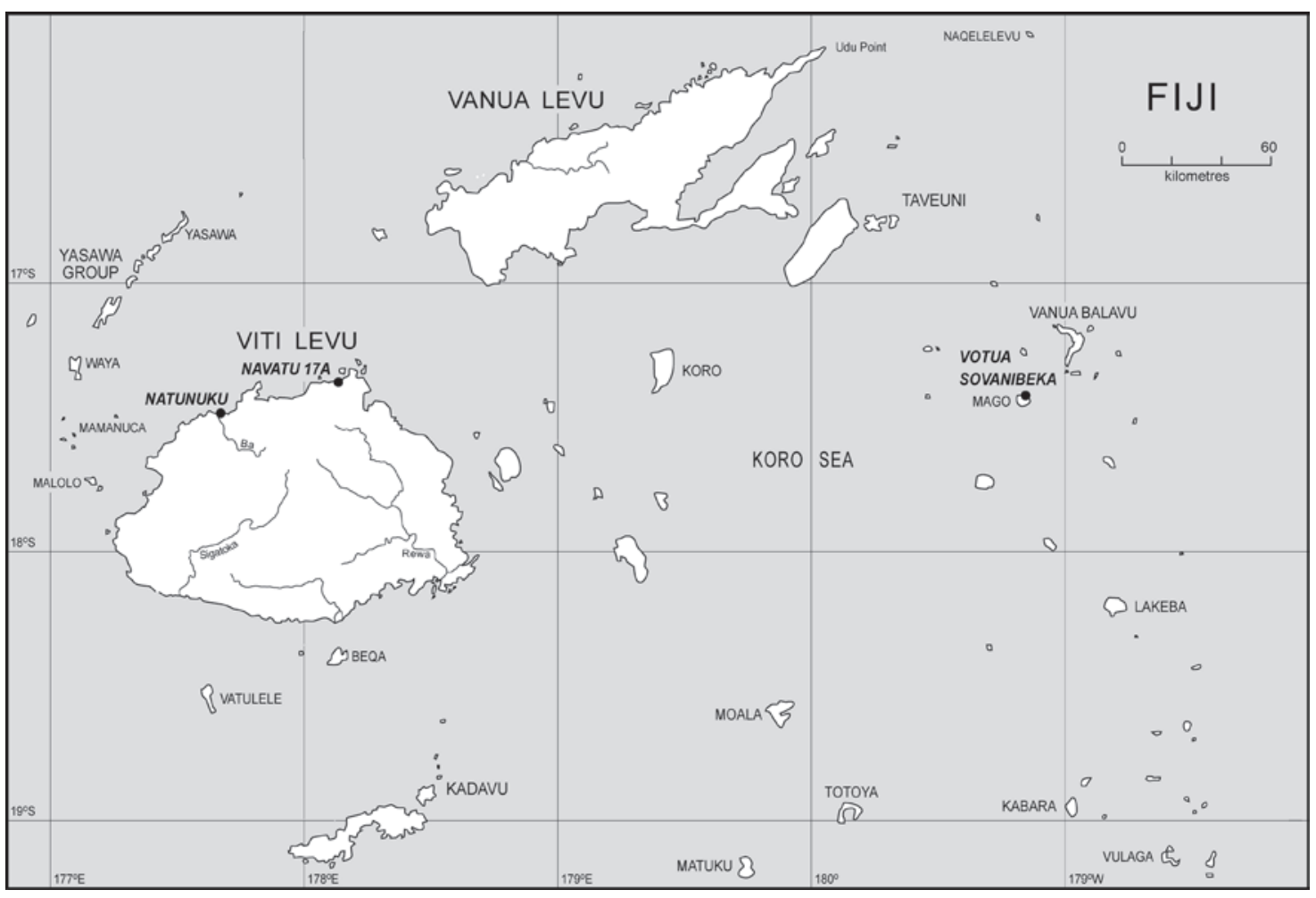

Figure 60. Map of Fiji showing research locations.

density of paddle-impressed sherds. To what extent this might be explained by disturbance was uncertain, and as the details of excavation had not been published by the excavators, and only so far as was necessary to put their analyses in context by Davidson et al. (1990), further research was called for. There had been a small test excavation, east of the main Lapita site, by Terry Hunt (1980:128), which produced a plainware vessel, but otherwise no additional fieldwork at Natunuku.

When our fieldwork took place in 1996, the evidence seemed to be that the site was probably not as old as the initial radiocarbon date had suggested, and the distribution of Lapita materials was very restricted. Revised correction of GaK-1218 by Davidson et al. (1990:131) indicated that a better estimate of its conventional age would be about $2800 \pm 90$ BP. Additional dates on marine shell by Davidson and Leach (1993) showed that Layer 5, including 5b, probably dated to about $350 \mathrm{BC}$, i.e. post Lapita. They went on to say that the Lapita assemblage had probably been confined originally to Layer 6 in Location $C$ and that Lapita sherds were absent from the other areas tested in the 1967 excavations (Locations A and B). They doubted that any of Layer 6 remained, due to coastal erosion.

\section{Fieldwork objectives}

Our research set out, nevertheless, to establish whether there was still a Lapita level at Natunuku, and whether it was possible to recover more from it than the exclusively ceramic assemblage that had been excavated in 1967, and to obtain additional samples for dating from Layer 6 . As at Sigatoka, we wanted to establish whether the Natunuku Lapita horizon represented the first occupation of a coastline that had been available for settlement for a substantial period, or merely the settlement of a surface which had recently become available. For various reasons, these objectives turned out to be more difficult than we anticipated. 


\section{Site location}

The major problem was the most basic - where, in fact, was Location C? Davidson et al. (1990:Figure 3) showed the localities excavated in 1967 in relation to a sketch of the coastline and the disposition of the old coastal village and cemetery. In advance of fieldwork this seemed sufficiently precise to find Location C. However, as soon as the shape of the shoreline and the position of the drain and creek mouths were understood, and approximate measurements taken by pacing and tape measure, it became apparent that there was a substantial error.

In the 1990 map, the main identifiable features of the shoreline (which is about $700 \mathrm{~m}$ long between mangrove stands at either end) are the mouth of the swale that runs behind and parallel to the shore (it runs much further west than shown in the 1990 map), and indentations which approximate the location of a creek mouth about 40 m east of Location C in the 1990 map and a drain mouth adjacent to Location B (Davidson et al. 1990:Figure 3). Both watercourse mouths can be seen very clearly on the 1967 aerial photo (Figure 61). The 1990 map makes Location $\mathrm{B}$ about $330 \mathrm{~m}$ west of the swale mouth, while our measurements put this position at about 260 m west. Similarly, the 1990 map makes Location C about 445 m west of the mouth of the swale. This was particularly difficult to understand. According to the site description (Davidson

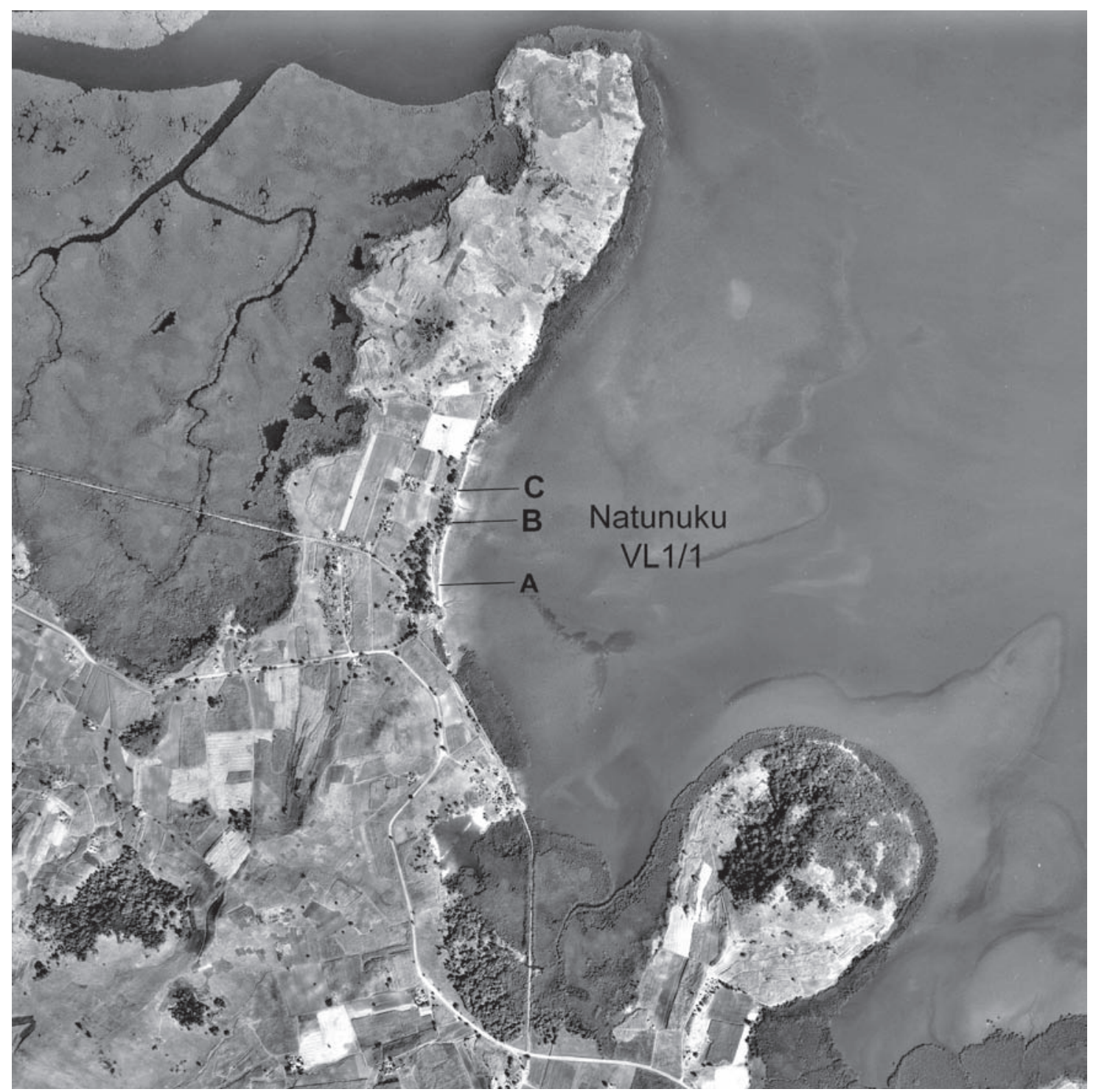

Figure 61. A 1967 aerial photo of Natunuku (courtesy of Elizabeth Hinds), showing the area of the site, on the coast between Locations $A$ and C. The old village site extends approximately between Locations A and B. 
et al. 1990), Location C lay on the front beach ridge, within the cemetery and (contrary to its accompanying map), east of the creek mouth and cane fields. On our measurements, a locality $445 \mathrm{~m}$ west of the swale mouth was well into the cane fields where neither beach ridge nor cemetery exists and the land slopes gently to the shore. Our initial impression of a substantial locational problem was substantiated by a total station survey of the beachfront and its salient features (Figure 62).

The one certainty was that Location $\mathrm{C}$ lay within the old cemetery, which extends about $115 \mathrm{~m}$ between the drain mouth and the creek mouth, to a maximum distance of about $360 \mathrm{~m}$ west of the mouth of the swale. Location $\mathrm{C}$ must have been in that area, but where? Inspection of the coastal area and discussion with Natunuku village elders, including the former Headman, Mr Penaia Natanu, who had worked on the 1967 excavations, reached the conclusion that Location $\mathrm{C}$ had been located immediately west of the exposed beach rock platform that lies on the west side of the drain, and therefore quite close to Location B.

The grounds for this were: (1) Mr Natanu recalled that our Trench 3 and Location C were essentially adjacent and both close to the grave of his grandfather. In fact, his recollection was that Location $\mathrm{C}$ lay between our Trench 3 position and the drain to the east, and he said that the excavations were about $1.2 \mathrm{~m}$ deep through brown sand and terminated in yellow sand - a plausible description of the Location C stratigraphy; (2) the exposed beach rock platform, above which Trench 3 is located, is a prominent feature along the shoreline, and it appears to be shown in Davidson (1990:Figure 4) as extending into Location C; (3) at no other place along the shoreline, at least as it could be observed in 1996, was there beach rock exposed so high in the section - in fact at $1 \mathrm{~m}$ high it was still lower than the estimated $1.5 \mathrm{~m}$ beach rock face which lay beneath Location C; (4) the beach ridge above the beach rock platform is well within the surface distribution of Lapita sherds.

Against this hypothesis were the following considerations: (1) Mr Natanu also recalled that two pits were excavated in 1967 about $50 \mathrm{~m}$ west of the beach rock platform, near the creek mouth. No sherds were recovered but a skeleton was found and it had a diamond-shaped shell pendant associated with it. He thought it was a modern burial and the pendant chain had rusted away. We cored and dug a spade hole in this area (under the ST4 point in Figure 62), but it is just low ground close to the water table (at $0.5 \mathrm{~m}$ depth) and has no archaeological remains; (2) although the grave shapes and disposition in the Location C plan (Davidson 1990:Figure 4) are quite distinctive, we could not match this arrangement on the ground; (3) the consensus of local opinion was that the shoreline had receded about 5-6 $\mathrm{m}$ in the centre of the bay since 1967, which on the face of it would have removed Location C almost entirely.

Subsequent to fieldwork, Dr E. Hinds (neé Shaw), now deceased, kindly provided copies of some unpublished plans of Natunuku (E. Hinds, pers. comm., Dunedin). A small-scale sketch map of the site (distances converted by us from imperial to decimal) shows Location B at about $280 \mathrm{~m}$ west of the swale mouth and area C, about $365 \mathrm{~m}$ west of that point. These figures are closer to our own than to those in Davidson (1990:Figure 3), but still different (e.g. our surveyed map puts the drain near location B at $260 \mathrm{~m}$ west of the swale mouth). More importantly, the Hinds map has Location B marked east of the drain, by about 35-50 m, and Location $\mathrm{C}$ midway between the drain and creek mouths, both of which are noted on the plan. This would put Location $\mathrm{C}$ within the approximate position shown in our Figure 62. Simon Best (pers. comm., Auckland) had reached the same conclusion about Location C in discussion of our surveyed map of the site.

As the Hinds map is the only original document we have seen which marks the positions of Location $\mathrm{B}$ and $\mathrm{C}$ in relation to the shape of the coast and the positions of the stream mouths, we are inclined to accept it. The important implication would be that our Trench 3 was, after 


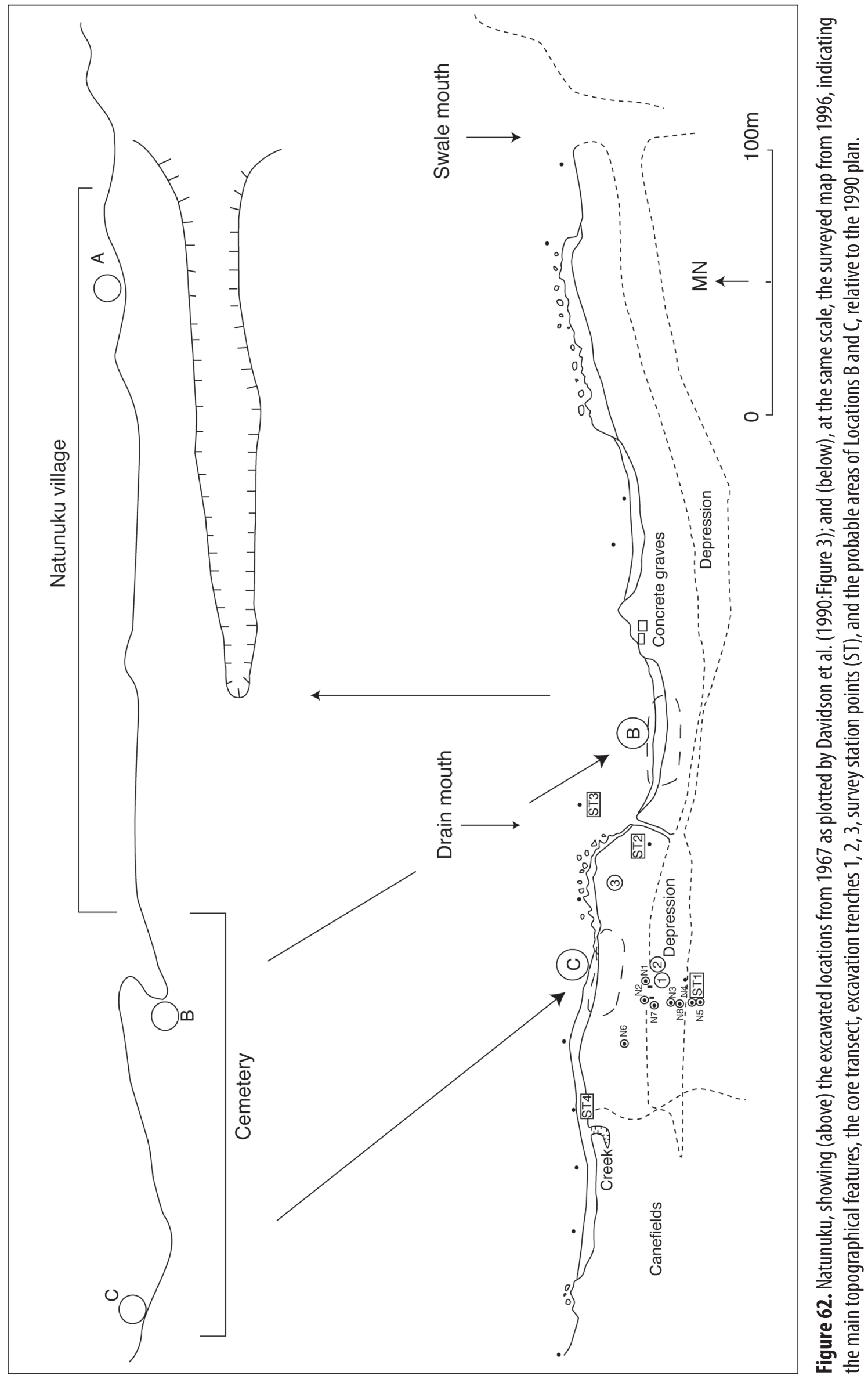


all, significantly east of Location C, probably by at least $20 \mathrm{~m}$, and it could not be expected to disclose the same stratigraphy and contents. Nevertheless, the distribution of Lapita ceramics extended well outside Location $C$ and included the areas of our excavations. In fact, Lapita pottery can be picked up on the surface along approximately $100 \mathrm{~m}$ of the coastline west of the drain and for $20 \mathrm{~m}$ back to the northern slope of the swale. It is probable, therefore, that Location C and our excavations both sample the same ca. 2000 sq. m Lapita site.

\section{Geomorphological investigation}

Behind the shoreline beach ridge the swale extends much further west than is shown in the 1990 map or the Hinds sketch map. As indicated in our surveyed map (Figure 62), there are two basins to the swale, and they are linked by a narrow channel, running through beach rock, which also occurs in the sides of the swale, especially on the south side. While the eastern basin of this feature might have been dug in the 1920s (Davidson et al. 1990:122), there is no reason to think this was also true of the western basin or the connecting channel. Geomorphologically, these appear to be natural features. The western basin holds some depth of water quite often, according to local residents. It can spill out through the creek or through the cut drain when that is cleaned out. Assuming the western basin of the swale existed in the Lapita era, it would have been a useful source of freshwater on a coastline where creeks are often dry, and possibly a significant locational attraction.

In order to investigate the relationship of the Lapita site to the surface on which it was deposited, we cored on a transect through the swale and on to the top of the first beach ridge, although several core holes, notably N6, were displaced from the transect line to avoid beach rock or graves (Figure 62). This exercise showed that the basic sedimentary sequence, bottom to top, is as follows (Figure 63):

1. Dark-grey to blue, and occasionally rust-red, estuarine mud of a type found in mangrove environments. This is commonly encountered at $2.0-2.5 \mathrm{~m}$ below the beach ridges where it generally corresponds in depth with the water table. In some core holes this deposit appeared to keep on going and became so wet that the core could no longer recover any sediment. In N1-2, the estuarine mud bottoms out on an indurated shelly surface with large shells and coral. Elsewhere (N5, N4, N3 and shoreward of N6) there is beach rock at the base of the penetrable sediments.

2. Compact, orange-brown, gritty, shell hash, with small pieces of coral, some basalt cobbles.

3. Grey-white granular sand, often quite loose, with abundant shell, large lumps of rock and large pieces of coral and beach rock. It appears to have formed in a relatively high-energy beach environment.

4. Light-brown to grey-yellow, fairly compact, calcareous sand, originally a beach deposit, but with significant quantities of fragmented shell, silt and clay. No pottery was recovered but there were some large, unbroken shells. The sand becomes coarser with depth, and silt and clay are in higher proportions towards the top.

5. Dark-brown silty sand which appears to have been a forest soil. This is rich in archaeological remains. In core N6, this is overlain by a deposit of the light-brown calcareous sand which probably arose from grave-digging. Also in that core was a layer of orange-brown silty sand and clay, which contained large shell pieces, whole shells and beach rock. It was not found elsewhere. 


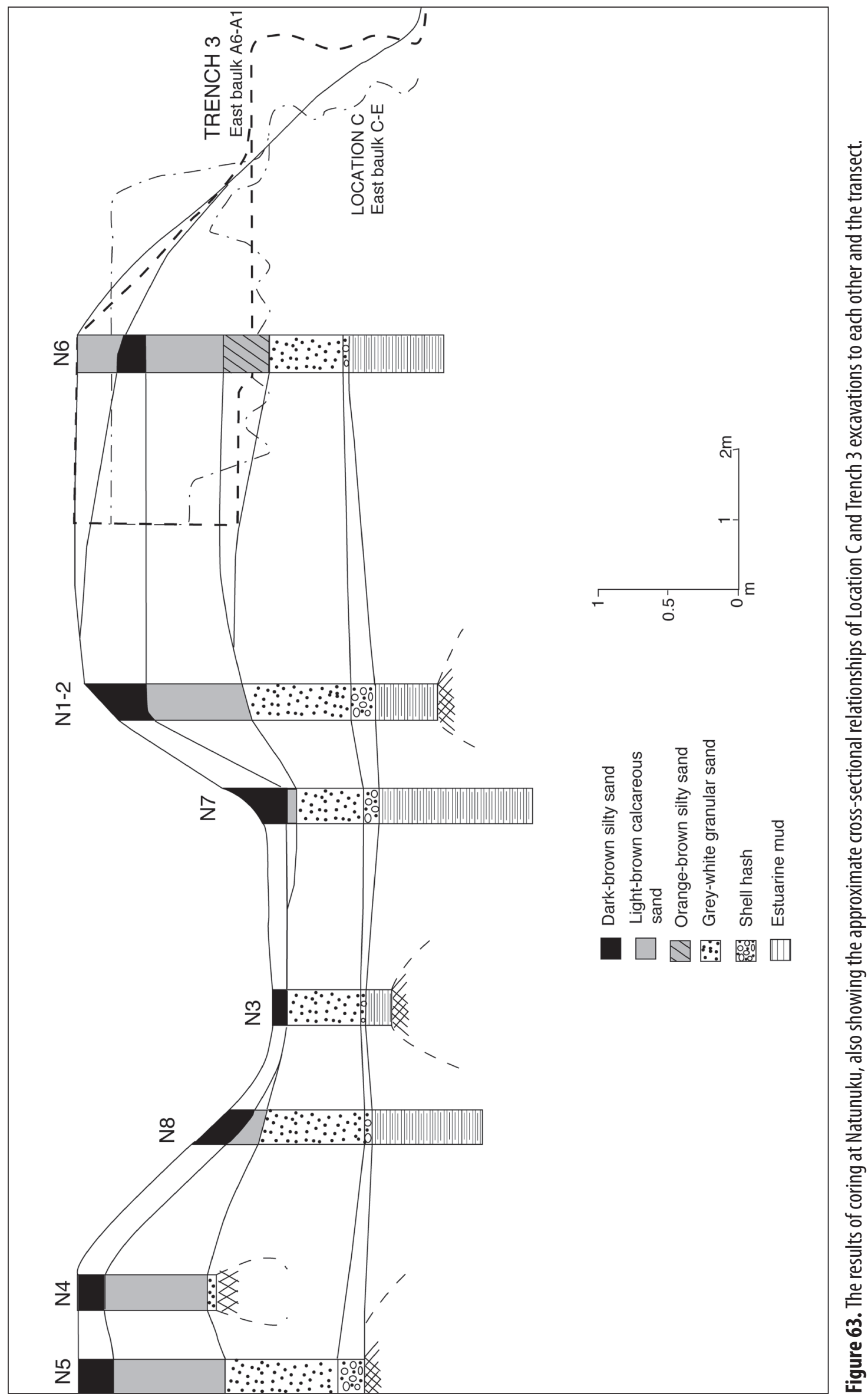


In summary, it appears there was a higher and more active beach level than today, formed above an estuarine mud. The beach extended to at least $2 \mathrm{~m}$ above present high-tide level (consistently with Nunn's (1990) observations on the coral stacks to the east of Natunuku Bay). As sea level fell, the highest sediments were washed out to form the swale behind the present shoreline beach ridge; that being protected, perhaps, by a substantial underlying platform of beach rock. Key (n.d.) suggests there are two successive beach-rock levels at Natunuku. One, outcropping at the shore, is $1-1.3 \mathrm{~m}$ thick, and the other outcrops on the south side of the swale. It follows from this geomorphological history that the shoreline beach ridge and swale probably existed for some time before human habitation.

Turning to the Location C stratigraphy (Davidson et al. 1990:126), Layers 1 and 2 appear to have been deposited recently about the graves and along a path between them. These units are localised and were not found in our excavations. Layer 3 is the dark-brown silty sand and clay, seemingly a forest soil, which occurs at the top of the natural sedimentary sequence. Layer 4 is the light-brown calcareous sand and silt that underlies it in the natural sequence. Layer 5 appears, by description, to have been dune sand and it overlies apparent beach sand filled with cemented coral sand and beach rock (Layer 6), which, in turn lies on an irregular surface of the beach-rock platform. Layers 5 and 6 do not occur in our core transect and it is difficult, therefore, to understand them in relation to a broader coastal sequence. However, Layer 5 is at the same relative elevation as the light-brown calcareous sand in the natural section and is, we assume, a variation of it. Layer 6 appears to have been a clean yellow beach sand and cemented material, which contains only Lapita pottery and no other cultural material beyond a few flecks of charcoal. It might be equivalent to the orange-brown sand found in core N6 and further coring might have shown that this increases in depth and lightens in colour shorewards. Certainly a similar coarse, yellow sand with cemented lumps lies at the base of the Trench 3 excavation. It is possible pottery was re-deposited into Layer 6 by wave surge at some point during the Lapita era.

\section{Excavations in 1996}

Observing the wider than expected surface distribution of Lapita sherds, we set out two small excavations on the north slope of the swale (Trenches 1 and 2) and one (Trench 3) on the seaward face of the beach ridge (Figure 62). Excavation was by $10 \mathrm{~cm}$ spits within natural layers and material was sieved to $3 \mathrm{~mm}$ in the sandy layers, but often to only $6 \mathrm{~mm}$ in the stiff, blocky clay and loam layers, although material was well broken up to try to ensure that cultural material was not missed.

\section{Trench 1 (Figure 64)}

Layer 1: Light-brown sandy loam containing abundant shell and pottery. The shell was mostly oyster and Anadara, but also included Tridacna. Among the midden was some bottle glass and cattle bone. Lapita pottery was especially prominent and there were also pieces of shell armband and paddle-impressed ware.

Layer 2: Blocky, stiff, dark-brown sandy loam which was damp to excavate and dried very hard. Almost no midden or pottery was recovered.

Layer 3: Pale-yellow to grey compact sand, shell and coral. No cultural material was found. 


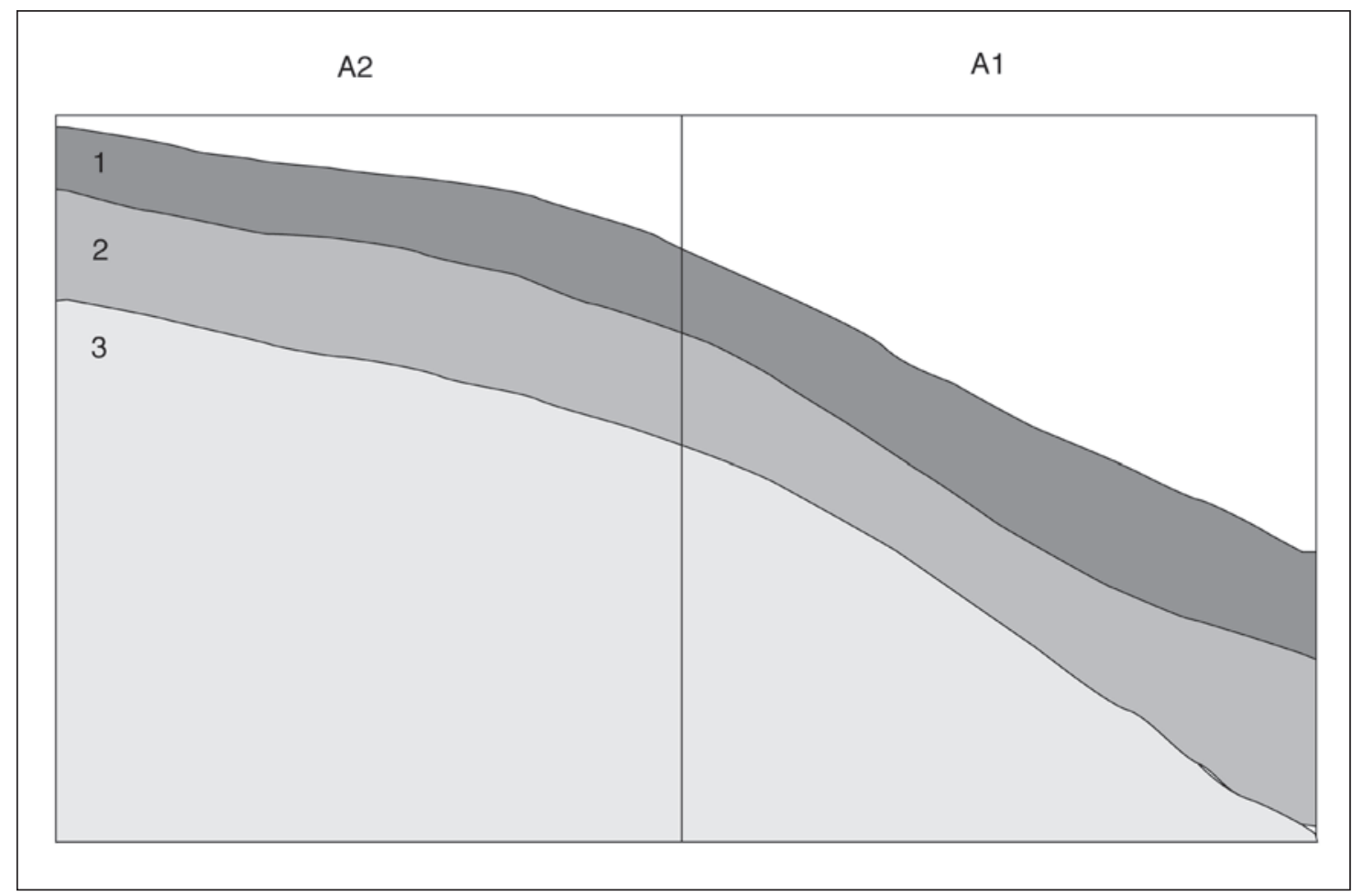

Figure 64. Stratigraphy of east baulk of Trench 1 (see text for layer descriptions).

\section{Trench 2 (Figure 65)}

Layer 1: Light-brown sandy loam containing abundant shell and pottery, again with Lapita sherds prominent. There were also pieces of shell armband, drilled shell pieces and plates, notched shell and other worked shell. Shell midden was less abundant than in Trench 1, but Lapita sherds were correspondingly more abundant. In Square 2, at $20 \mathrm{~cm}$ depth, a Lapitastyle ceramic handle was found in association with two brass tap fittings.

Layer 2: Yellow-brown sandy loam full of shell midden and some pottery.

Layer 3: Blocky, stiff, dark-brown-to-black sandy loam which was damp to excavate but dried very hard. Very little midden or pottery and nearly all of it near the top.

Layer 4: Coarse, pale-yellow to light-brown calcareous sand with natural shell fragments and coral. No cultural material.

Layer 5: Damp grey-yellow coarse sand with much broken shell.

Trenches 1 and 2 appeared to contain, at the surface, re-deposited layers of the lightbrown calcareous sand, presumably from grave-digging on the top of the beach ridge. This unit contained most of the cultural material and in Trench 2 a thin layer of it also occurred beneath the original forest soil, which was essentially bereft of cultural items. Excluding the probable re-deposition by natural down-slope movement and grave digging, the stratigraphy in this area suggests it is right on the margins of the Lapita site. Disturbance was clearly extensive, including by land crabs. 


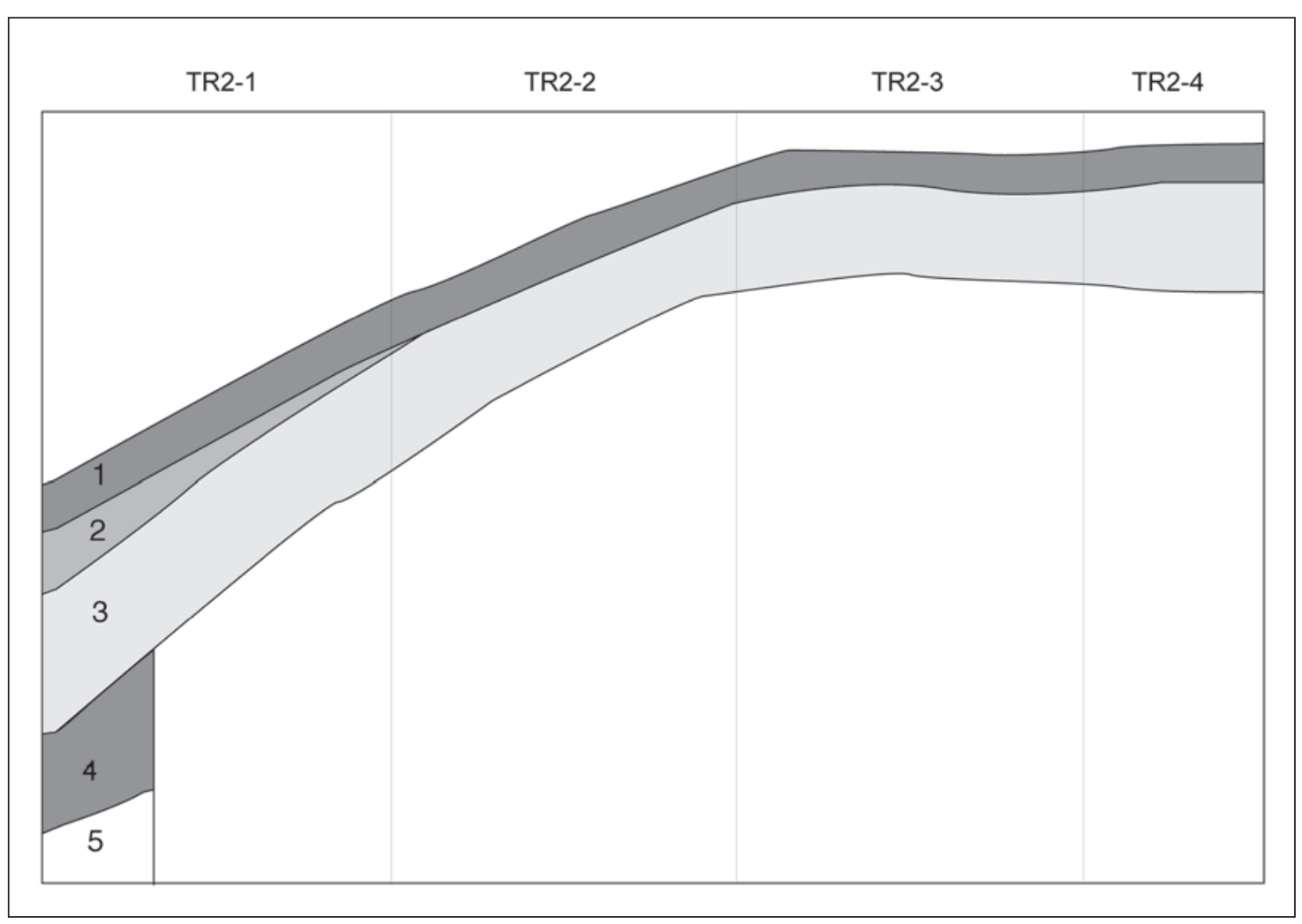

Figure 65. Stratigraphy of west baulk of Trench 2 (see text for layer descriptions).

\section{Trench 3}

This was an 8 sq. $m$ excavation set out on the top and seaward slope of the beach ridge. In areal extent, it was the same size as the combined rectangles which were fully excavated in Location C (Davidson et al. 1990:125), and so far as can be judged from the description of Location C, and the published and unpublished (E. Hinds, pers. comm., Dunedin) sections, both Trench 3 and Location $\mathrm{C}$ represent essentially the same cross-sectional positions across the beach ridge and above the beach-rock platform (Figure 62). Nevertheless, they differ in cultural levels and content. The stratigraphy of Trench 3 from the top of the beach ridge was as follows; here from the west baulk of Square B6 (Figure 66).

Layer 1: $0-10 \mathrm{~cm}$ of weakly developed turf on friable light-brown sandy loam. Small quantities of shell and pottery.

Layer 2: $10 \mathrm{~cm}$ to $40-50 \mathrm{~cm}$ of a slightly sandy, compact dark-brown silt loam. Abundant shell and other midden, burned and cracked basalt and pottery. Decorated sherds of the latter were nearly all Lapita.

Layer 3: From base of Layer 2 to $50-70 \mathrm{~cm}$ depth of yellow-brown, humus-stained sand, with very little midden or pottery, and that mostly near the top.

Layer 4: This is a coarse, yellow, calcareous beach sand with much coral and broken shell. It closely resembles the description of Layer 6 in Location C (Davidson et al. 1990), but it contains no cultural material.

Other squares in Trench 3 were variations on this pattern, thinning seaward to Square A1 which had, under a thin turf, just a $1-3 \mathrm{~cm}$ layer of coarse, pale-yellow to grey sand above the 


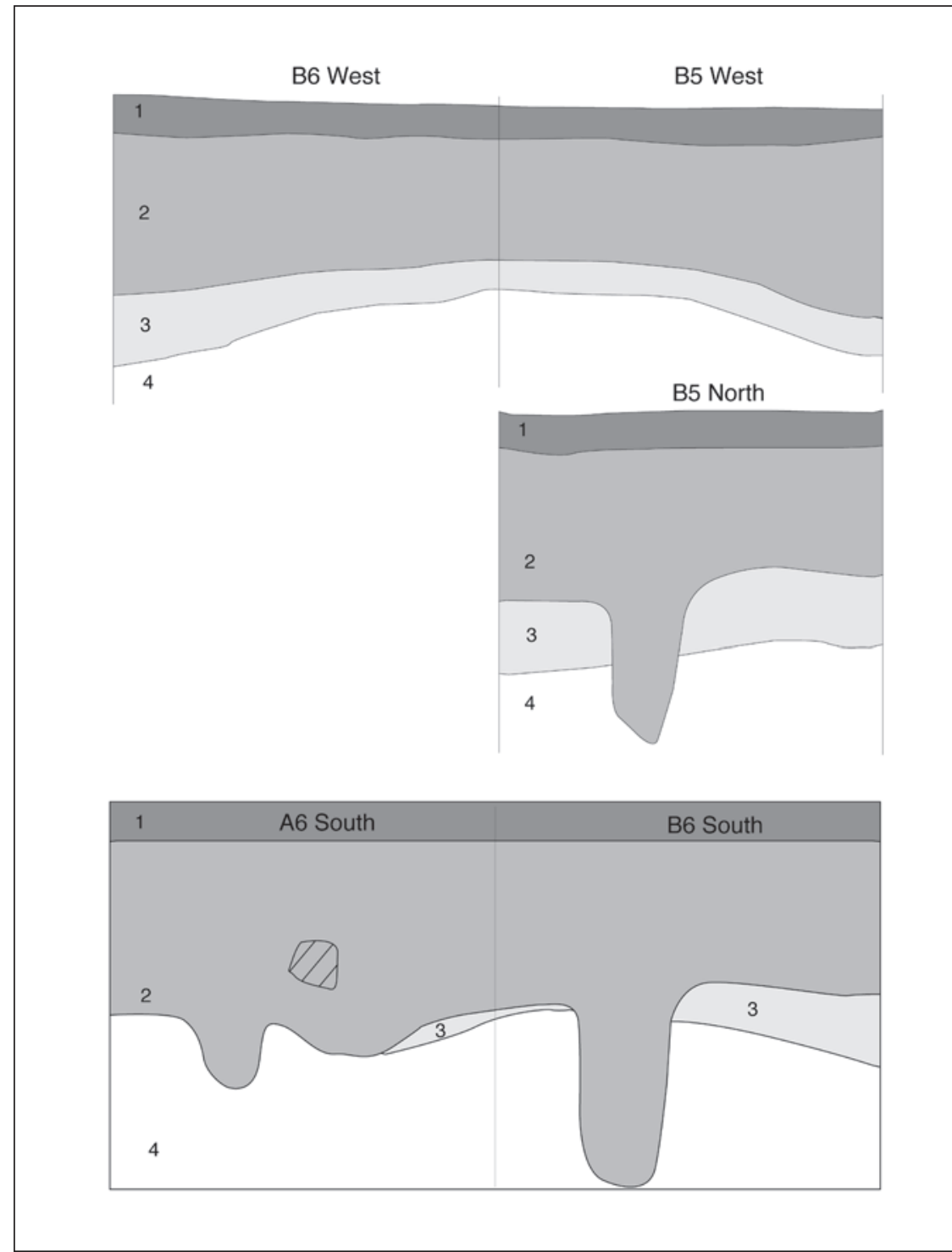

Figure 66. Stratigraphy of west baulk of Squares $\mathrm{B} 5$ and $\mathrm{B} 6$ (above), and south baulk of A6, B6 (below) in Trench 3 (see text for layer descriptions).

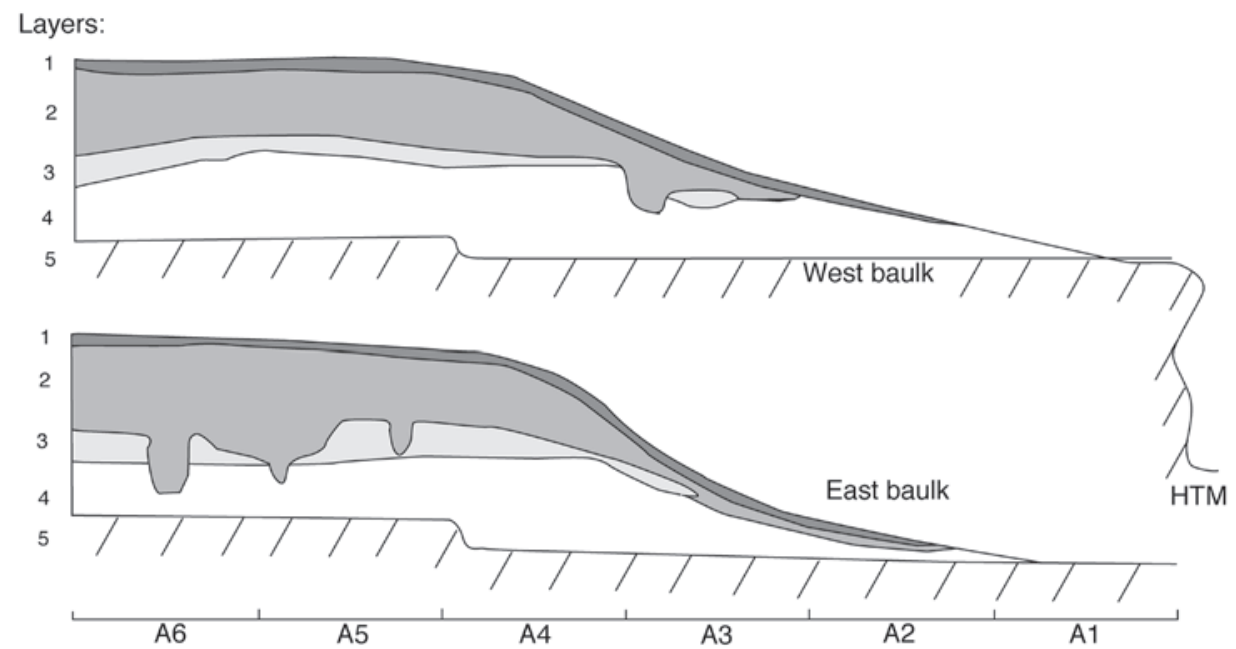

Figure 67. Stratigraphy of west (above) and east (below) baulks of the Trench 3 excavation (see text for layer descriptions). Both lie on a beach-rock platform at approximately $1 \mathrm{~m}$ above high tide mark. 
beach-rock platform (Figure 67). Trench 3 stratigraphy had been substantially disturbed by ovens and post holes, cut from within Layer 2 and reaching to the base of the site (Figure 68), and also by land crabs. No post butts remained and it is impossible to be certain of the agency involved in each feature, but Feature A, which was packed with broken rock (although almost no charcoal), had probably been an oven. Features B, D, E, F, M and O seem to have been post holes. The others are enigmatic. They may have been post holes that were exploited subsequently by burrowing crabs.

Overall, the stratigraphy could be regarded as combining Layers $1-4$ and 6 of Location C (Davidson et al. 1990), but with Layer 5 absent. It is possible that both the existence of Layer 5, an apparent dune sand, and the deposition of Lapita sherds in Layer 6, are quite localised phenomena. Now that it is possible to define the area of Location $\mathrm{C}$ more precisely, those issues need to be tested.

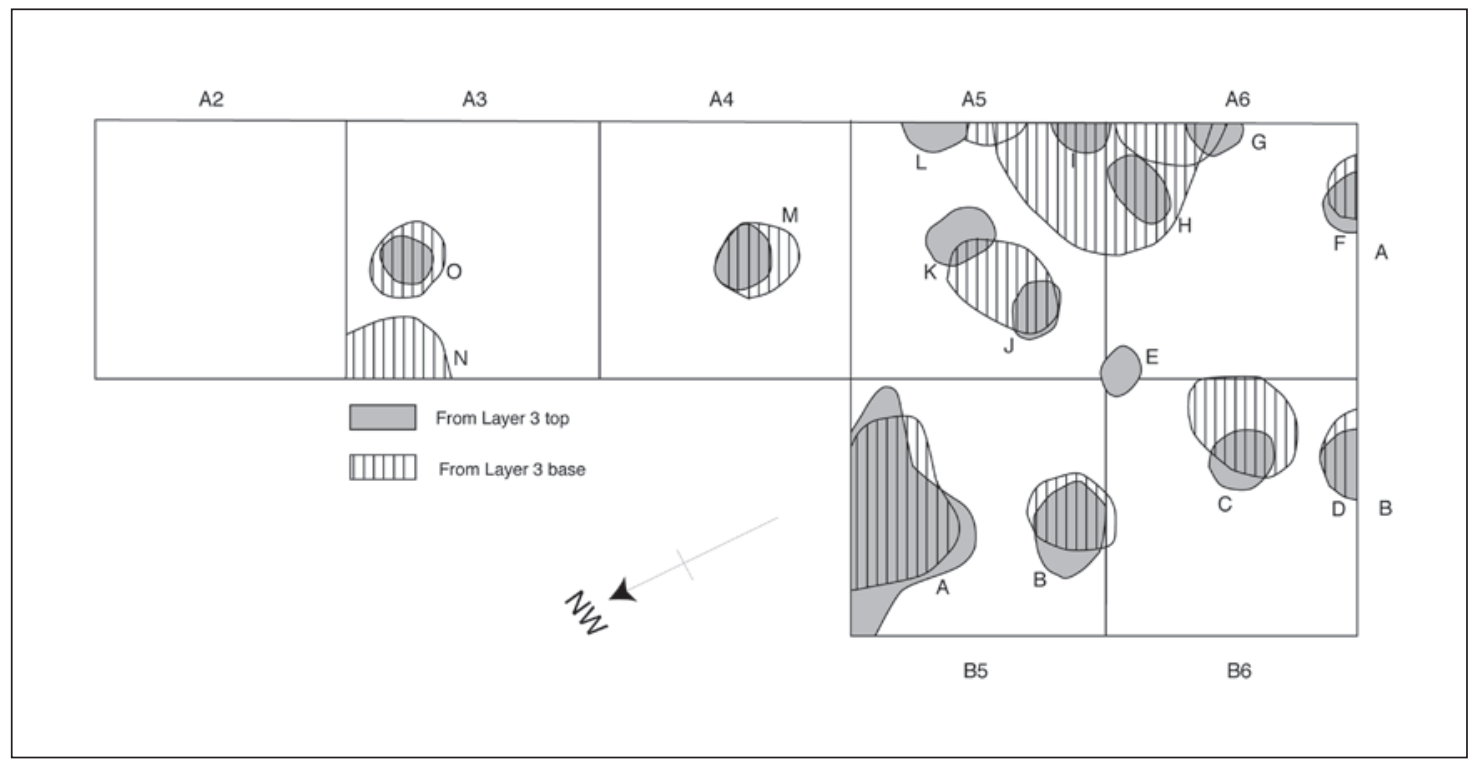

Figure 68. Features in Trench 3 at Natunuku, as seen at the top of Layer 3, and at the base of Layer 3. See text for suggested interpretation.

\section{Fieldwork at Navatu, 17A}

Navatu 17A was first excavated in 1947 by Edward Gifford, then aged 63 and Director of the Museum of Anthropology at the University of California. In a landmark paper published in 1963, Roger Green re-evaluated Gifford's material and divided Fiji's past into four phases, the longest of which (100 BC to 1100 AD) was called the Navatu phase after the site located in northern Viti Levu. Navatu 17A was re-excavated in 1996 as part of a wider investigation into the post-Lapita period of Fiji, and focused on obtaining pottery and dating samples to refine the chronology and stylistic content of the Navatu phase. Geomorphological investigations of the slope deposit and alluvial flat were made during recovery of a core for pollen analysis (Chapter 4).

The eponymous site for the Navatu phase is located on the western side of a volcanic plug, known as Uluinavatu (head of the rock), in the province of Ra, on the north coast of Viti Levu (Figure 69). In traditional history, Uluinavatu is one of the jumping-off places for spirits and was a famous refuge. In 1876 when Sir Arthur Gordon visited, there were three 'villages' on the plug, with the uppermost used as a refuge during warfare (Derrick 1951:195). Traditional and historical information concerning the area is summarised by Gifford (1951, 1952a), Frazer 
(1963) and Parry (1997). Their accounts suggest that within Ra Province the movement of people was frequent due to the expansion of the Colo tribes from the interior as well as feuding among coastal vanua (group of related yavusa).

The volcanic plug has a maximum height of $198 \mathrm{~m}$ and is $0.8 \mathrm{~km}$ in diameter. It is composed of hornblende andesite of Pliocene age (Seeley and Searle 1970; Rodda 1976), and separates the coastal villages of Narewa to the west and Vitawa to the east. To its north, the plug is bordered by the mangrove-fringed coast, along which runs the light rail line built by the Colonial Sugar Refining Company. South of the plug, the King's Road divides the rocky and steep slopes of the volcanic plug from the low-lying alluvial flats used for cropping and grazing (Figure 70), with the steep Nakauvadra Range (altitude $750 \mathrm{~m}$ ) lying $6 \mathrm{~km}$ behind the plug.

Vegetation covering the plug is dominated by vaivai (Leucaena glauca), an introduced legume. In recent years, the lower slope of the plug has been cleared for a variety of economic plants, especially cassava (Maniot utilissima), coconut (Cocos nucifera), banana (Musa sp.) and breadfruit (Artocarpus altilis). The flat area between the base of the western plug slopes and the Narewa creek is used for growing sugar cane (Saccharum officinarium) and grazing horses, cattle and goats. Small plots of taro (Colocasia esculenta) are grown along the sheltered sides of the Narewa stream.

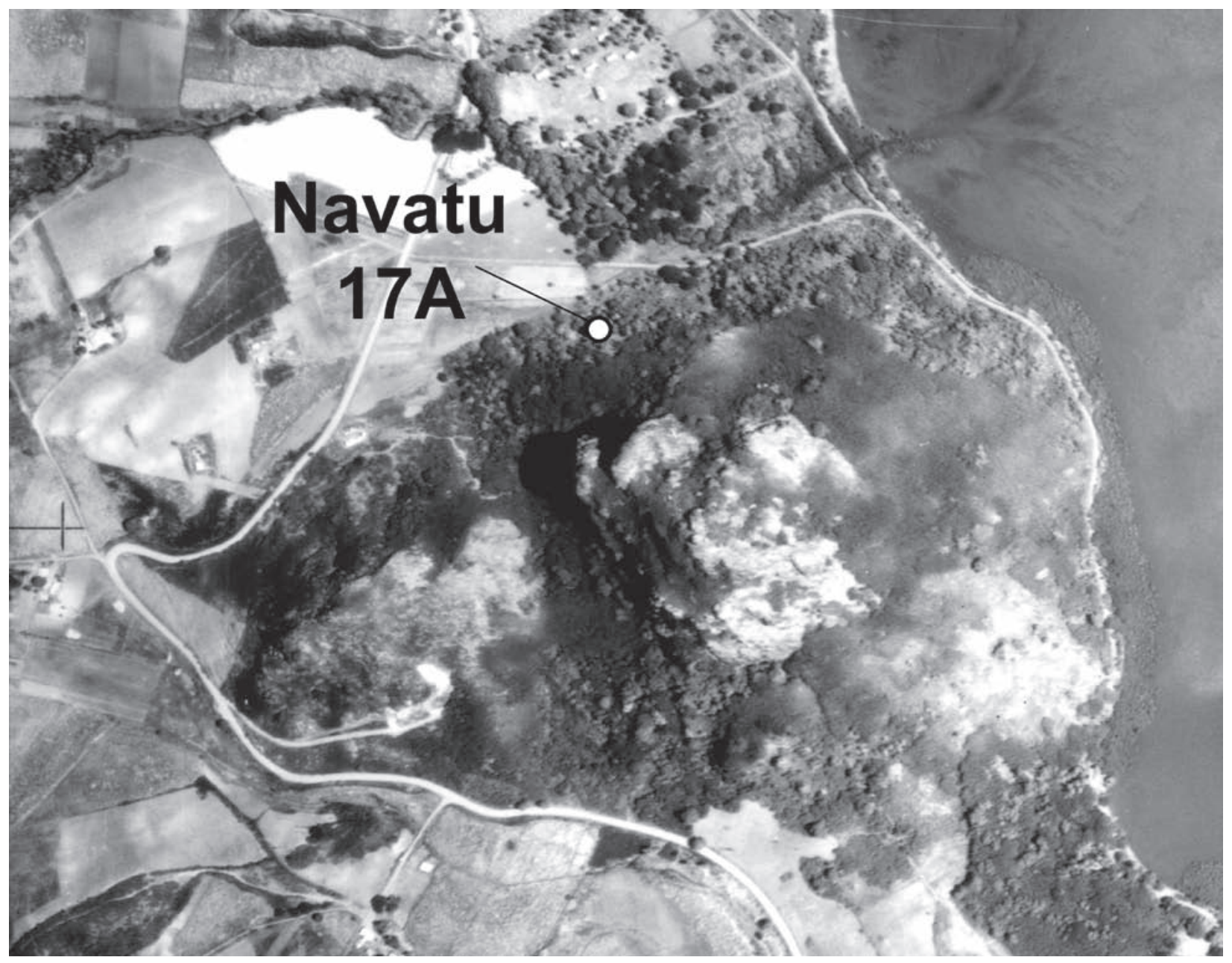

Figure 69. Aerial photograph (pre-1970) showing the location of Navatu 17A on the flank of Uluinavatu. 


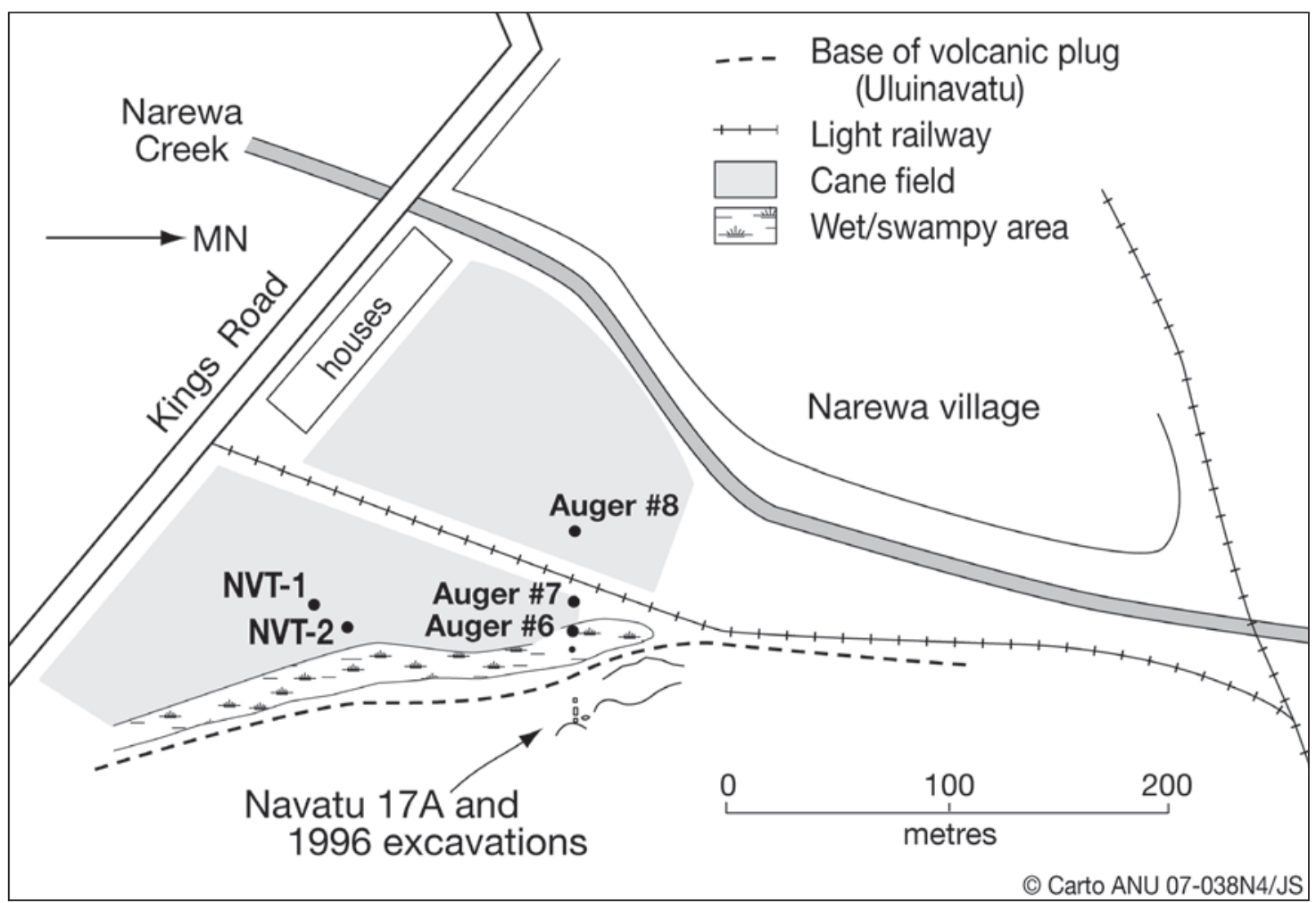

Figure 70. Navatu 17A, plan view of site location and environs showing auger and pollen core holes.

\section{Excavation}

The site of the 1947 investigations was located by reference to Gifford's site map (1951:Diagram 1) (Figure 71). Visible signs of the earlier excavations were found inside the small rock shelter, where the eastern extant of squares U3-5 could still be seen, and possibly on the slope surface, where an east-west depression corresponds with the difference in slope height recorded by Gifford (1951:Diagram 2).

A $1 \mathrm{~m} \times 15 \mathrm{~m}$ transect was set out roughly parallel to the previous excavations. Isikeli Donu of Narewa village, who had worked with Gifford (Figure 72) in 1947 (Gifford 1951:Plate 14a), confirmed that the 1996 excavation transect was broadly parallel to and slightly north of the 1947 transect. Three trenches were laid out along the transect and positioned approximately east-west so as not to overlap with the earlier excavations (Figure 71).

Trench A was immediately in front and north of the rock-shelter entrance. The trench consisted of a $1 \mathrm{~m} \mathrm{x} 3 \mathrm{~m}$ rectangle. The top (eastern) metre square was designated A1 and the bottom A3 (Figure 71).

Trench B was just over $3 \mathrm{~m}$ down-slope from Trench A and was originally $1 \mathrm{~m} \times 3 \mathrm{~m}$ in size. This trench was later extended by $1 \mathrm{~m}$, as large boulders occupied much of Squares B2 and B3. The eastern $1 \mathrm{~m} \times 1 \mathrm{~m}$ square was designated B1 and the western square, B4 (Figures 71 and 73).

Trench $\mathrm{C}$ was situated on relatively flat ground near the marshy zone which lay between the plug slope and the cane fields. However, the amount of water at that location, either from a spring or the natural water table, halted investigations at $80 \mathrm{~cm}$ depth and Trench $\mathrm{C}$ was abandoned. It is possible that water-logged archaeological deposits occur in the vicinity of Trench $\mathrm{C}$ as there was apparently no diminution in cultural material in a core taken down to $1.2 \mathrm{~m}$ depth.

Excavation was by $10 \mathrm{~cm}$ and $20 \mathrm{~cm}$ spits within each natural layer. Two $20 \mathrm{~cm}$ spits were used for the first $40 \mathrm{~cm}$ of the deposit, and then consecutive $10 \mathrm{~cm}$ spits were taken. Matrix 


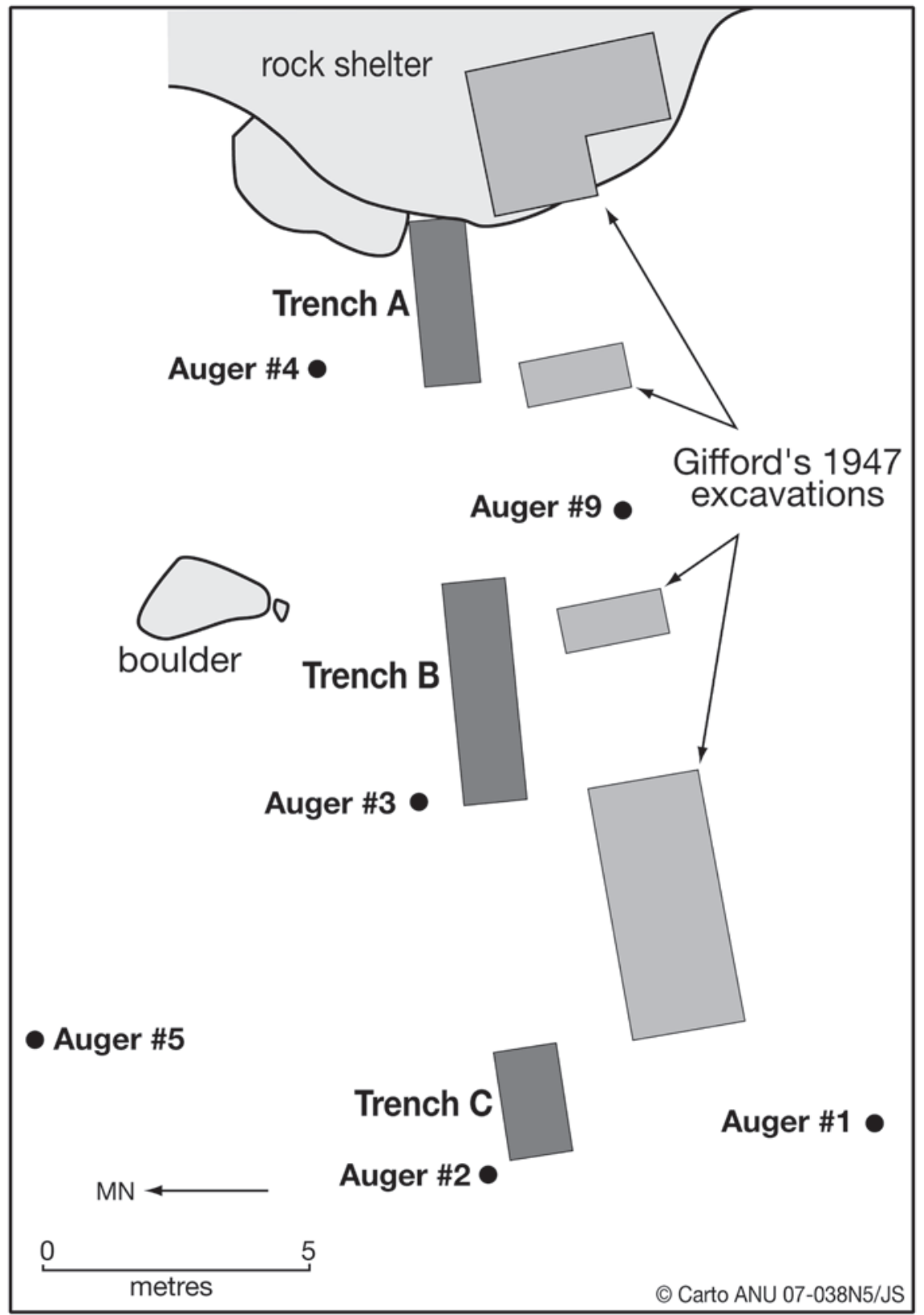

Figure 71. Navatu 17A, plan view of previous (1947) and recent (1996) excavations.

material was sieved using $3 \mathrm{~mm}$ and $6 \mathrm{~mm}$ mesh. However, the lowest deposits consisted of a wet, sticky clay that required washing and some hand-sorting to separate cultural material from sediment. Layer 4 (see below) was excavated as two units $(\mathrm{B} 1+2$ and $\mathrm{B} 3+4)$ because of large andesite boulders in Squares B2 and B3 (Figures 74-75). A $50 \mathrm{~cm}$ x $50 \mathrm{~cm}$ column from the northeast corner of Trenches $\mathrm{A}$ and $\mathrm{B}$ was retained as bulk sample.

Four layers were identified during excavation of Trench B. Three of these contained cultural materials, while Layer 3 did not. The layers were not found in all excavated areas and the lowest cultural deposit, Layer 4, was identified in Trench B only (Figure 73 and Figure 75).

Layer 1: Consisted of a very dark-brown silty clay (10YR 3/1, pH=6.75). The depth of this layer varied due to the slope angle, the presence of large boulders and the effects of recent gardening. In general, Layer 1 was around $1-1.5 \mathrm{~m}$ in depth. Cultural material included large quantities of pottery sherds, marine shells, boulders and fragments of andesite, and charcoal. Several concentrations and horizontal lenses of shellfish remains were found at 


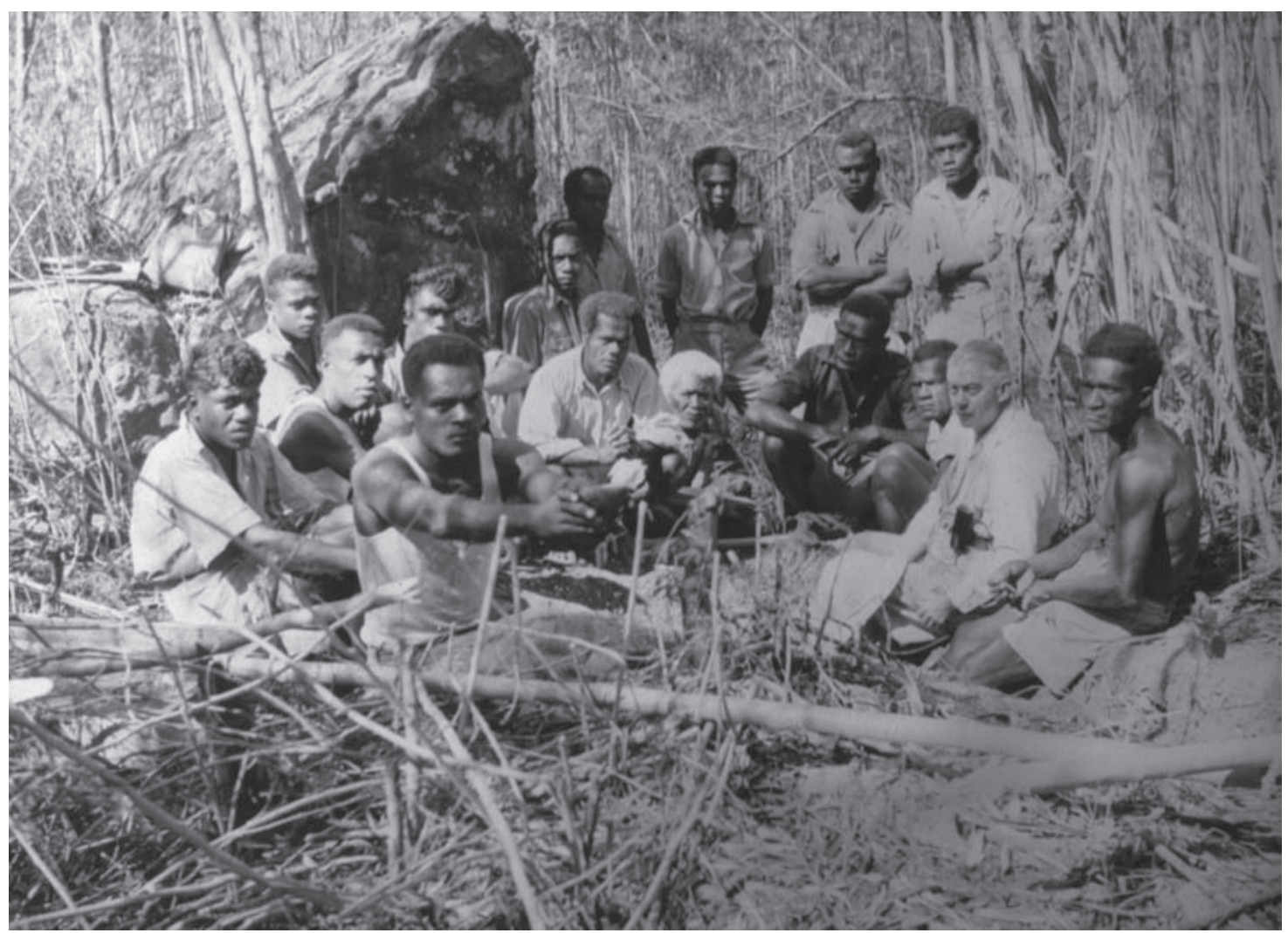

Figure 72. Edward Gifford and work crew at Navatu-Narewa (see Gifford 1951:Plate13c). Photo courtesy of David DeGusta.

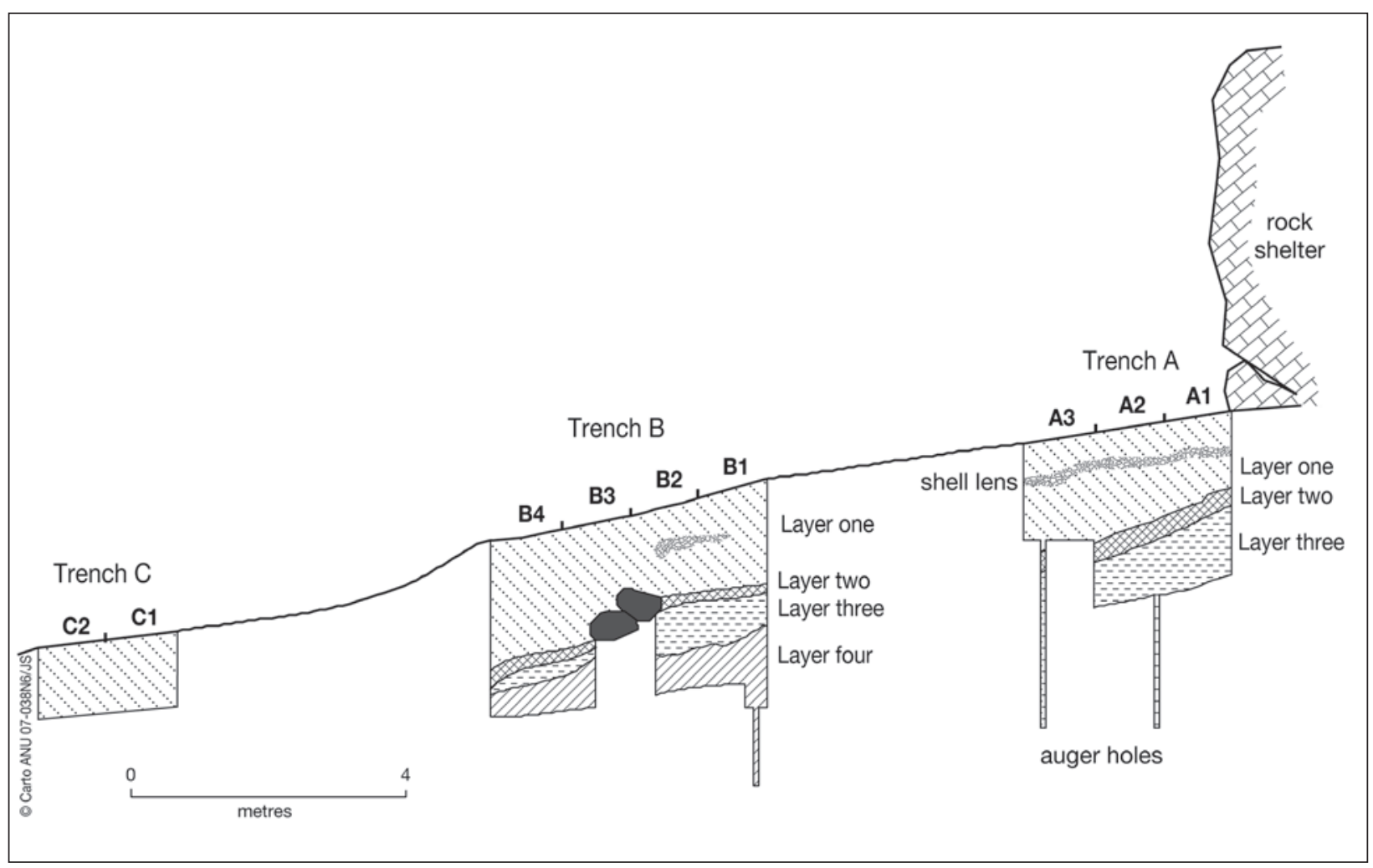

Figure 73. Navatu 17A, north section of 1996 excavation trenches. 


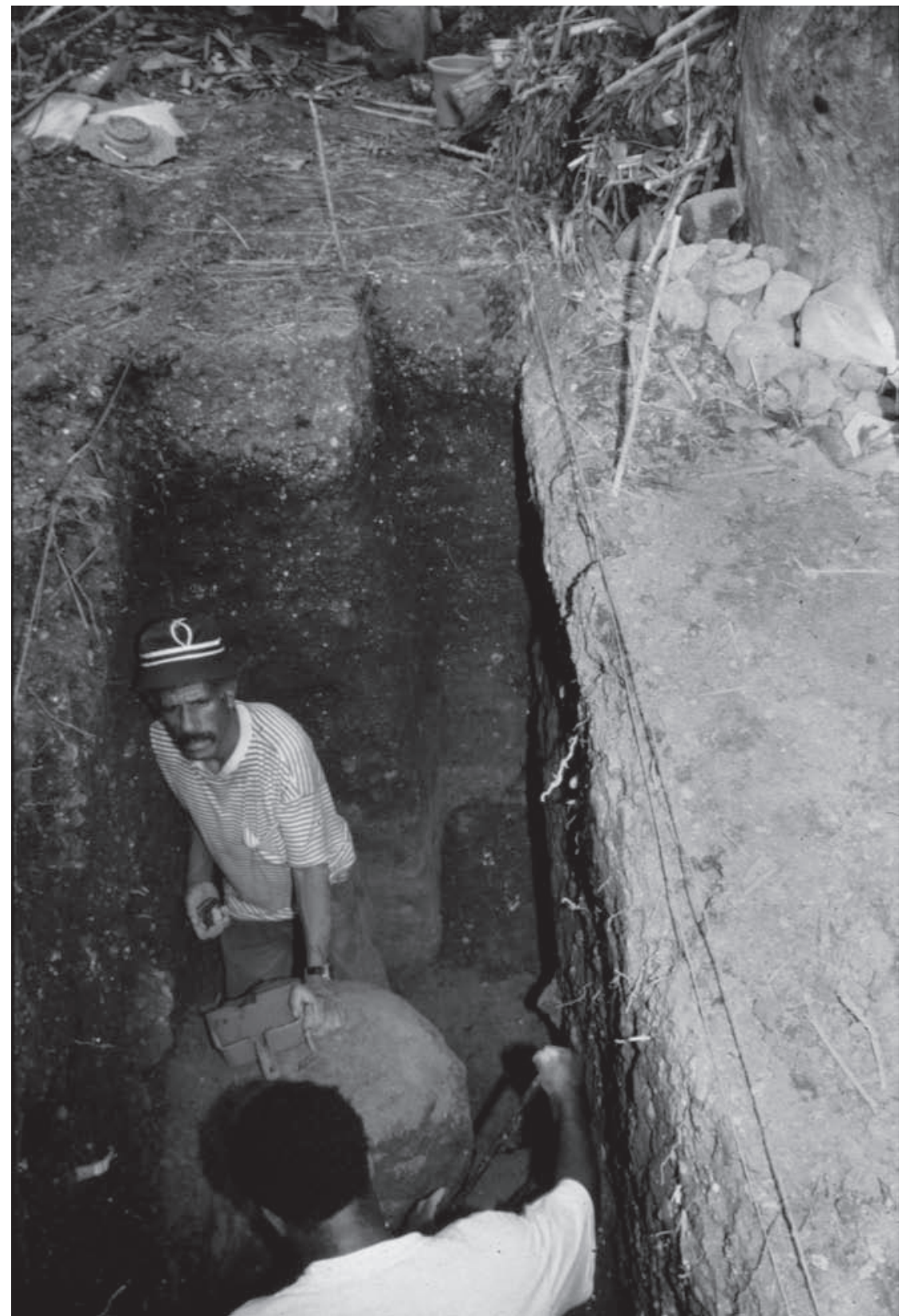

Figure 74. Navatu 17A, Trench B excavation east baulk of B1.

50-80 cm (Figure 73 and Figure 75). Distinctive comb-incised sherds, which occur on the slope and circumference of the Navatu plug, were primarily confined to the first metre of this layer.

Layer 2: A dark-brown silty clay. The layer was found in Trenches A and B, and also identified in a nearby auger hole. The colour of this layer varied from a dark yellowish-brown (10YR $6 / 6)$ at its base to a dark brown (10YR 3/3, $\mathrm{pH}=6.75)$ where it merged with Layer 1 . The layer depth varied from $10-50 \mathrm{~cm}$. There was a low density of cultural remains, which were primarily shellfish and ceramics, with small quantities of bone and charcoal flecks. Ceramic sherds were mostly plain but included small and eroded specimens marked with wavy, parallel and cross-hatch paddle relief.

Layer 3: A mottled yellowish-brown material (10YR 5/8, $\mathrm{pH}=7.0$ ). There was a gradual transition between this layer and Layer 2, suggesting development from Layer 3, whereas 
the Layer 3 boundary with Layer 4 was abrupt and consistent with an episode of very sudden deposition. No pottery, shell or charcoal was identified during excavation, and pollen and phytolith analysis of the Layer 3 sediments were also negative. The layer had a variable depth that was generally about $20-50 \mathrm{~cm}$ thick. In Trench A, coring into this layer showed that it graded into greyish-white silty clay below $3 \mathrm{~m}$ depth. The water table was struck at $3.8 \mathrm{~m}$, where the deposits had an increasing quantity of coarse sand. At the western end of Trench B, Layer 3 became less defined, possibly due to the placement of a linear stone feature.

Microscopic analysis of the Layer 3 sediment revealed a dominance of angular feldspars with accessory mica and ferromagnesian grains. No volcanic glass was observed, suggesting that significant weathering of the material occurred since deposition. John Chappell (pers. comm., ANU) identified this material as a reworked tephra that has been deposited downslope from the plug flanks.

Layer 4: A dark greyish-brown clay $(2.5 \mathrm{YR} 5 / 2, \mathrm{pH}=6.75)$ that graded into a light greybrown silty clay (10YR 4/2, pH=7.0) between $2.8 \mathrm{~m}$ and $3.0 \mathrm{~m}$ depth. The top of this layer contained quantities of weathered and often fragmentary marine shell. Small shell scatters occurred in the eastern part of Trench B and on the surface of Layer 4 (B1 and

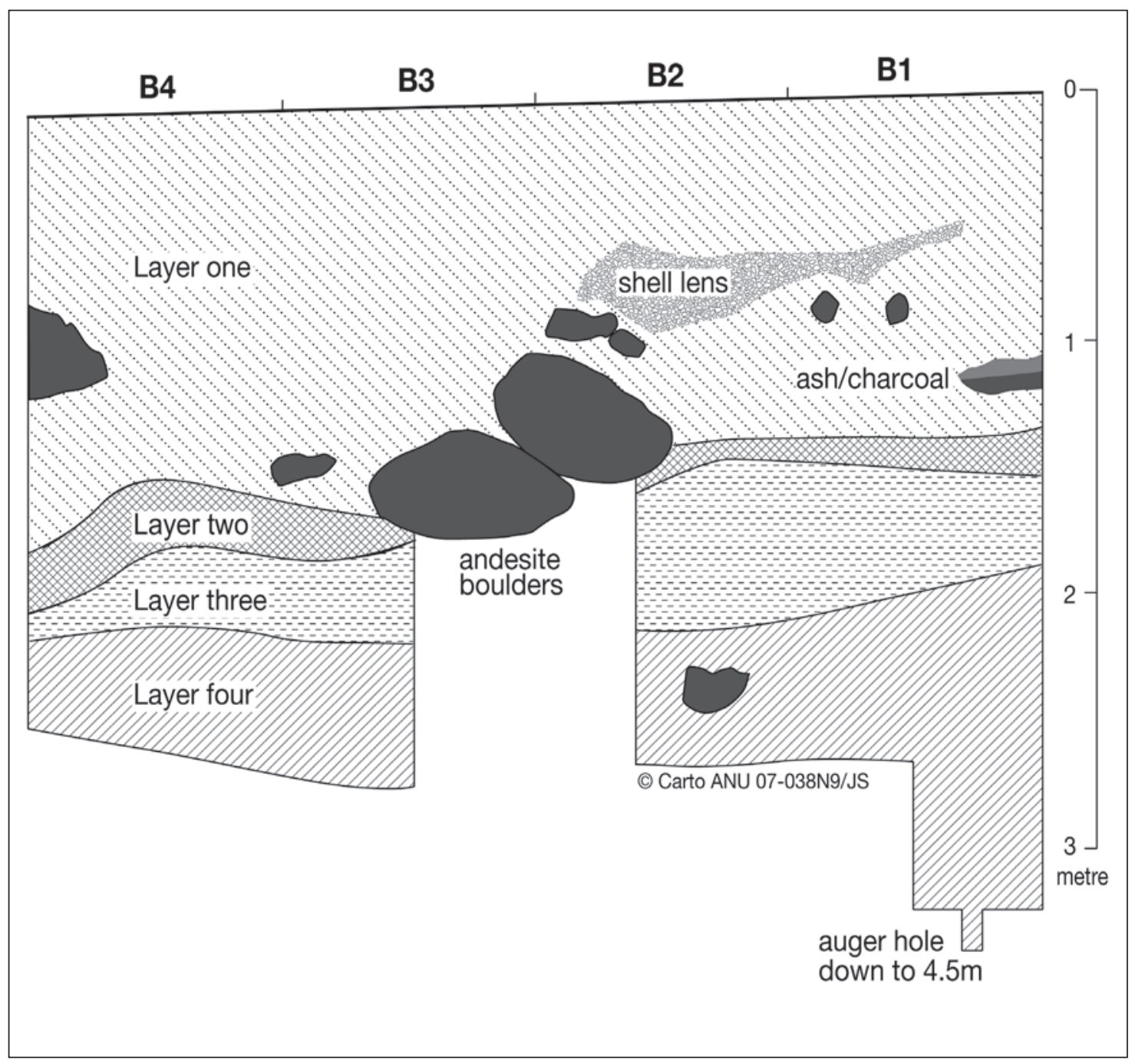

Figure 75. Navatu 17A, Trench B north profile (Squares B1 to B4). 
B2). Associated with the shell were ceramic sherds decorated with varieties of paddle- and tool-impressed decoration. No structural features or non-ceramic artefacts were recovered. Bones from fish, turtle, shark and human were present in small amounts.

Features included several small hearths recognised by concentrations of ash and charcoal in Layer 1 of Trenches A and B. Other Layer 1 features included clusters of marine shells, and a post hole was dug from Layer 1 or 2 into Layer 3 (Figure 76). The stone alignment found in the western end of Trench B at a depth of $70 \mathrm{~cm}$ could be a natural or a cultural feature. Evidence for the latter is suggested by Gifford, who noted two stone lines, which were identified as buried house-mound foundations in rectangles EF3-4 (Gifford 1951:Diagram 1 and Plate 13e). The feature found in Trench B (Figure 76) lies in the same line as that found by Gifford (i.e. the eastern end of Gifford's A3-4 to F3-4 rectangles). While most features were found in Layer 1, smaller patches of shellfish remains occurred in Level 4.

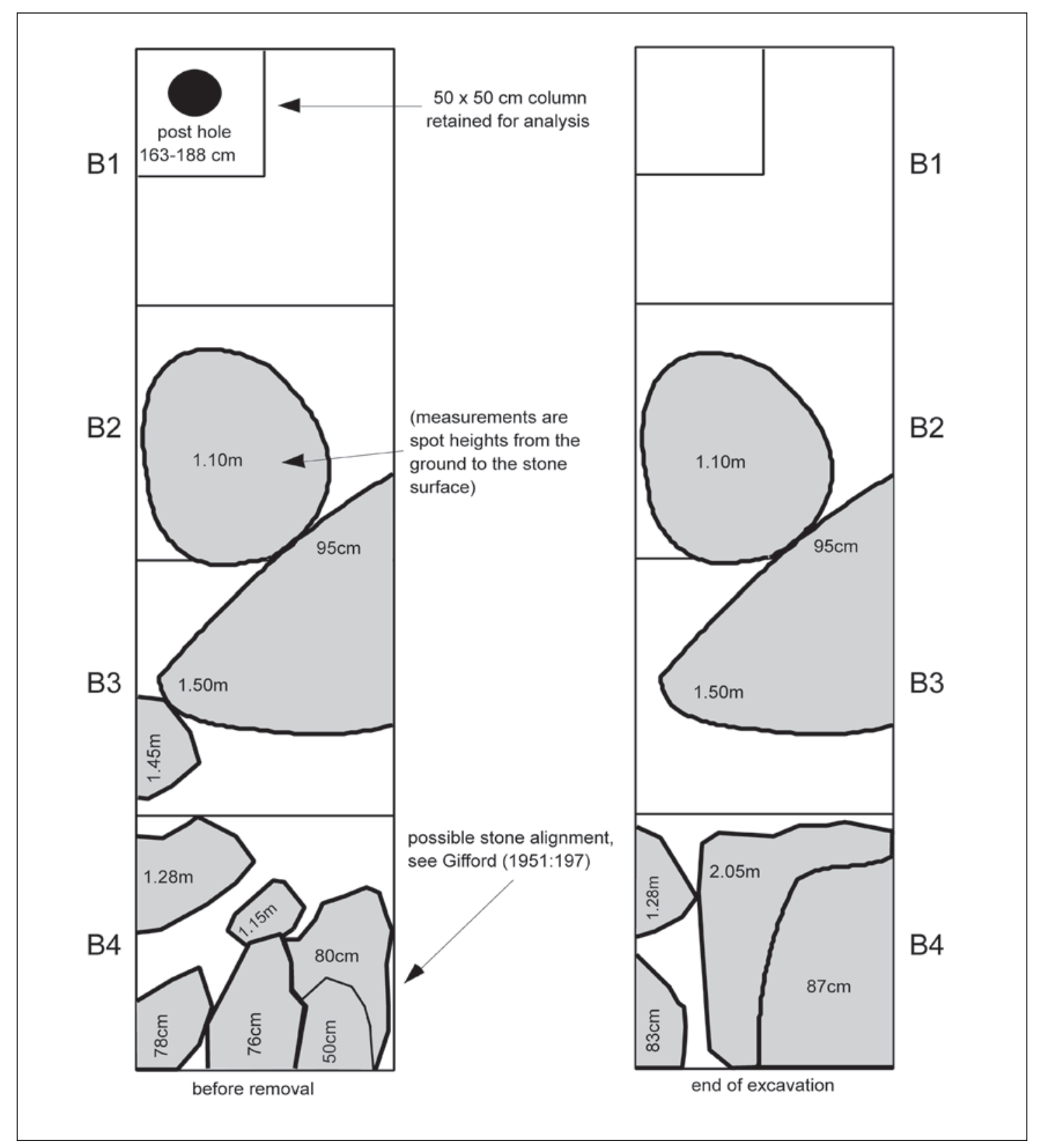

Figure 76. Navatu 17A, Trench B plan view before and after removal of stone feature. 


\section{Geomorphological investigations}

A transect line of four auger holes was taken to examine whether the heavy cultural deposits on the plug flank extended west to the alluvial flat (Figures 70-71). Holes were made with a manual auger equipped with soil and sand barrels (10 cm diameter), and their stratigraphy is described below and is summarised in Figure 77.

Hole \#5. Location $9.2 \mathrm{~m}$ north of the northeast corner of Trench C.

0-41 cm: Dark-brown silty clay with abundant marine shell and pottery.

41-57 cm: Dense concentration of burned and fragmented marine shellfish in ash.

57-100 cm: Light-to-medium brown damp soil with little shell or cultural material, except flecks of charcoal.

100-142 cm: Grey mud with inclusions of a brown moist soil. Small quantities of pottery, fish bone and a few small marine shells. Core finished on rock (basement or boulder?).

Hole \#6. Location $22 \mathrm{~m}$ west of the northeast corner of Trench C, on the edge of the swampy area near the base of the volcanic plug.

0-67 cm: Dark-brown puggy soil with orange-brown fragments of rotted rock.

$67-107 \mathrm{~cm}$ : Dark-grey soil with a plain pot sherd at $86 \mathrm{~cm}$.

$107-110 \mathrm{~cm}$ : Thin lens of grey sand.

110-197 cm: Grey-brown clay with orange fragments of rotted rock. Charcoal fragment at $1.42 \mathrm{~m}$ and water table reached at $1.70-1.80 \mathrm{~m}$.

197-274 cm: Dark-grey sandy silt with flecks of charcoal and two plain pot sherds.

Material too wet to remove below $274 \mathrm{~cm}$.

Hole \#7. Location $42 \mathrm{~m}$ west of the northeast corner of Trench C, in the sugar-cane field. 0-83 cm: Dark-brown soil with a pot sherd at $37 \mathrm{~cm}$ depth.

83-121 cm: Grey-blue clay mixed with brown soil. Ground water at $100 \mathrm{~cm}$ depth.

121-230 cm: Grey-brown fine silty mud. Some charcoal at $180 \mathrm{~cm}$.

230-235 cm: Grey-brown sand.

235-255 cm: Thin layer of brown soil with water-logged wood and charcoal.

255-344 cm: Black sandy-silt layer with inclusions of rock, clay and roots. Hole finished when wet sediments could not be collected.

Hole \#8. Location $72 \mathrm{~m}$ west of the northeast corner of Trench C, in the sugar-cane field. 0-81 cm: Dark-brown soil with flecks of charcoal.

81-167 cm: Light-brown soil with orange fragments of basalt and groundwater at $90 \mathrm{~cm}$. $167-197 \mathrm{~cm}$ : Blue-grey clay with fragments of charcoal.

The lowest deposit in Holes \#6-8 was an organic sandy silt, consistent with a swampy estuarine environment. Around $2 \mathrm{~m}$ depth this changes to a silty clay or mud with basalt clasts indicating that terrigenous sediments from the plug slopes, or more likely alluvium transported from the Nakauvadra catchment, had infilled the estuary. Except for a few fragments of charcoal, there is little evidence of prehistoric activity, other than in Hole \#6, near to the plug flanks, where cultural material was found below $2 \mathrm{~m}$ depth in waterlogged conditions. 


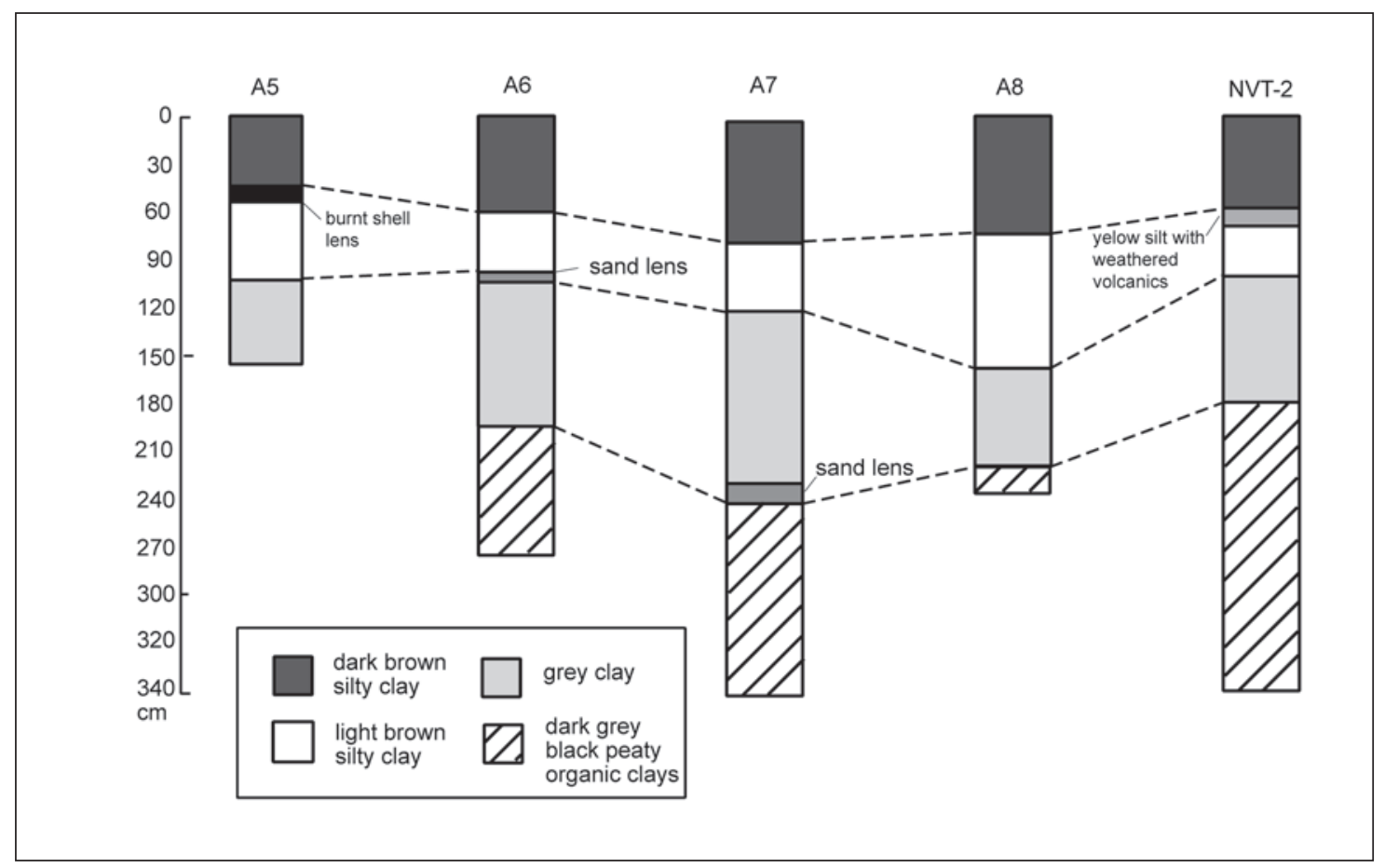

Figure 77. Navatu 17A, stratigraphy of auger and pollen core holes.

\section{Navatu 17A: Reassessment}

Two areas (A and B) at Navatu (Site 17) were excavated by Gifford in 1947. The main area studied by him was $17 \mathrm{~A}$. Navatu $17 \mathrm{~A}$ is below a large boulder of hornblende andesite. The boulder lies on the western side of the plug about $25 \mathrm{~m}$ from the edge of the cane field and ca. $4.5 \mathrm{~m}$ above the cane field. The boulder overhang forms a small $3.7 \mathrm{~m}$ deep shelter. Gifford staked $6 \mathrm{ft}$ x $3 \mathrm{ft}$ rectangles from the base of the slope up to the overhang. Stakes were labelled alphabetically in the east-to-west line and numerically north to south. Fourteen rectangles were opened up but the presence of andesite boulders and the high water table near the slope base meant that some rectangles were only partially excavated or were abandoned. The excavation transect included five rectangles within the boulder overhang, two separate rectangles on the mid-slope region and the major excavation region of five adjoining rectangles near the slope base (A3-4 to F3-4). Gifford's excavation measurements are given in metric units to allow comparison with the 1996 excavation details (Figure 71).

The cultural remains recovered by Gifford from Navatu 17A have been influential in interpreting Fiji's and the Pacific's prehistory, and the site's remains continue to be used to examine Fiji's past (e.g. Wahome 1995; DeGusta 1999). The longevity of Gifford's classic 1951 report, Archaeological Investigations in Fiji, ensued from several factors, particularly the high standard of analysis and reportage. Of note was the presentation of excavated material, particularly pottery attributes by depth (decoration type and weight), the identification of fauna, the first petrographic analysis of pottery (Curtis 1951; Dickinson 1971), and subsequently the first radiocarbon dates for Fiji and the first identification of fish remains from an archaeological site in the Pacific (Gifford 1952b, 1955; Fowler 1955). Surprisingly, at the time of the EFP investigations, Gifford's report contained the only published information about prehistoric fauna from a Viti Levu site.

The 1996 excavations demonstrated, however, that Navatu 17A is, like many archaeological sites in the Pacific, a complicated deposit and the new data allows substantial revision of its 
stratigraphy. The Navatu deposits were interpreted by Gifford through cultural content rather than by natural layer. Thus, the presence and amount of shell and the type of pottery decoration indicated significant temporal and cultural differences between 'Early' and 'Late' materials. This approach meant that a layer described by Gifford (1951:195) as a 'sterile volcanic ash' was not recorded as a separate stratigraphic unit although its upper surface was plotted (Gifford 1951:198). This layer clearly corresponds to Layer 3 identified in the 1996 excavations. However, while showing that this layer was found over the transect area, nowhere in the original report is there mention of an underlying cultural deposit that would correspond to Layer 4. However, as the 1947 excavations went down to $3.7 \mathrm{~m}$ depth in some areas, like the rectangle EF3-4, Gifford must have gone through the 'yellow-volcanic ash substratum' and recovered material from a layer equivalent to Layer 4 identified in the 1996 investigations.

The 'yellow volcanic ash' deposit - now identified as a redeposited tephra and called Layer 3 - is an enigmatic layer that is the basal deposit in the Trench A excavation but lies above Layer 4 in Trench B only $3 \mathrm{~m}$ down-slope. Because the transition between Layers 4 and 3 was abrupt, while the transition between Layers 3 and 2 was gradual, it is likely that Layer 3 was deposited suddenly. Such an interpretation is reliant on a nearby tephra source that remained in situ for some time. Gifford (1951:198) found the tephra layer over the length of his transect area $(18.3 \mathrm{~m})$, but did not record its presence from Site 17B some $400 \mathrm{~m}$ northeast of $17 \mathrm{~A}$. It seems probable that the tuff was deposited on the plug slopes some millennia ago, converting to a tephra over time. Near the plug base the tephra level was excised, possibly during periods of higher sea level or episodes of river flooding, but human activities might also have been responsible. Around 1000 years ago the tephra bank slumped on to Layer 4 for reasons that are currently unclear but which could include clearance of slope vegetation (natural or anthropogenic), severe storm events or human modification of the area.

The Layer 4 cultural deposits had a lower density than those from Layer 1. Ceramic sherds were not as abundant and the marine-shell remains had an eroded appearance that was similar to weathered shellfish fragments on the Layer 1 surface, suggesting a period of site abandonment. Cooking and consumption of marine foods and cannibalism were represented in Layer 4, but no evidence of ceramic production, artefact manufacture or structural remains was identified. The number of double-spouted vessels, the presence of decorated bowls and, if historical observations from the 19th century are germane, the presence of prestige food remains (human and turtle) in Layer 4 could result from a high-status occupation.

Following the deposition of the tephra Layer 3 deposit, cultural and faunal remains were even sparser in Layer 2, suggesting a period of relative abandonment. The development of a soil profile on the surface of Layer 3 supports this idea. The greatest concentration of archaeological remains came from Layer 1. Surface remains (ceramics and shellfish) from this layer covered the entire area surrounding the lower elevations of the volcanic plug, and penetrated into the estuary. The deposits appear to have built up relatively quickly and were associated with the construction of house platforms on the flanks of Uluinavatu. Thus, while the quantity of the Layer 1 cultural deposits suggests a more intensive use of the area than had previously taken place, the areal extent of the Layer 1 deposits indicates the involvement of a greater number of people than represented in Layers 2 and 4.

\section{Fieldwork at Votua and Sovanibeka, Mago Island}

Mago Island (Figure 78) consists of raised limestone on a submarine ridge, through which Miocene and Pliocene eruptions have deposited volcanic rocks over the limestone. The island lies $220 \mathrm{~km}$ northeast of Viti Levu and $90 \mathrm{~km}$ east of Taveuni, but several islands in northern 


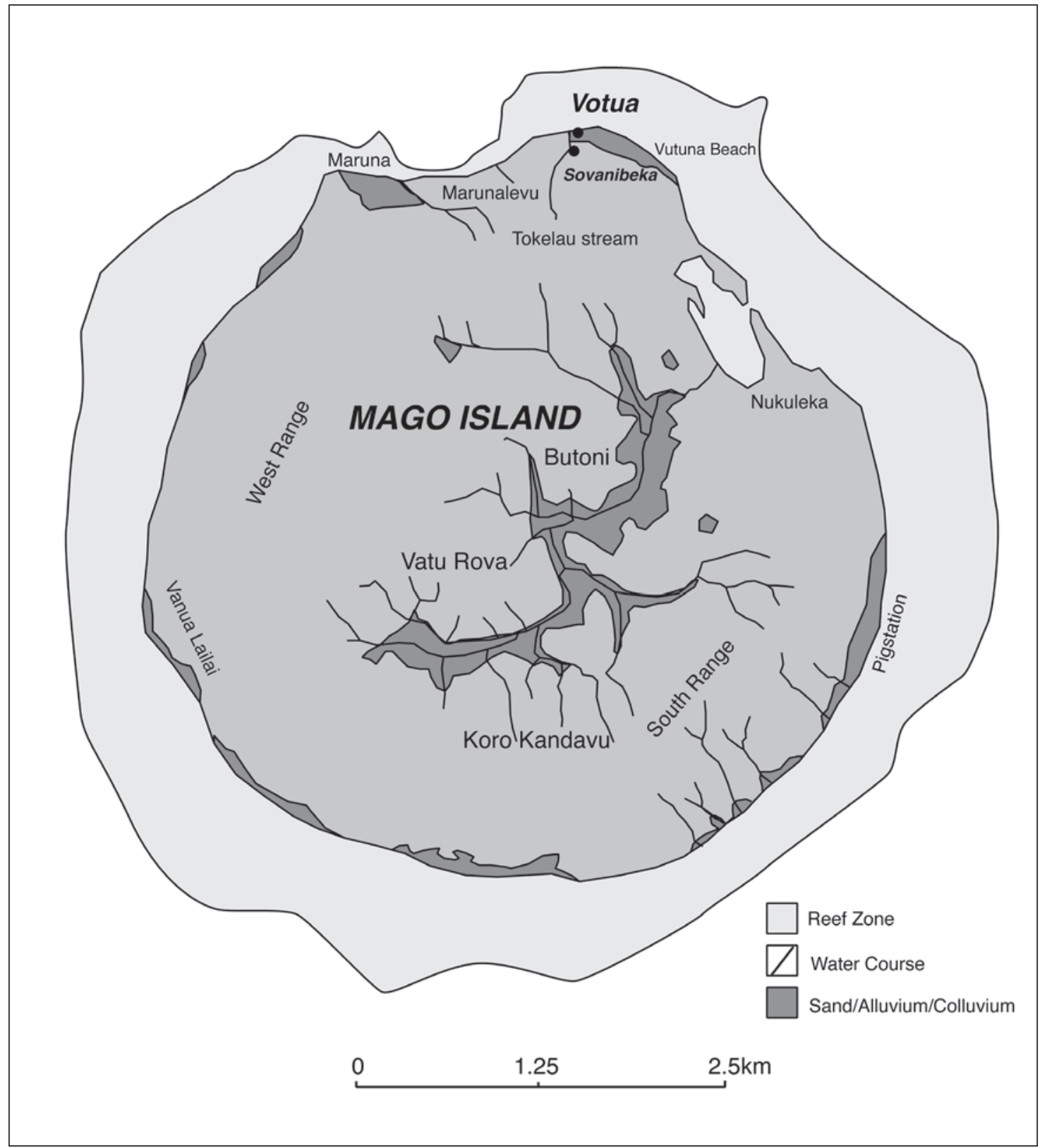

Figure 78. Mago Island and location of Votua and Sovanibeka.

Lau are visible from it, including Vanuabalavu. The physiography consists of steep weathered limestone ridges and plateaux bordering the coast, except in the north and southeast of the island, where volcanics have replaced limestone. Narrow coastal sand plains with a depth of up to $120 \mathrm{~m}$ are composed of carbonate sand and gravel of Holocene age, and are present discontinuously around the island (Ladd and Hoffmeister 1945; Woodhall 1985).

Excavations at Votua in late 1996 revealed an apparently single-phase late-Lapita site, which was first recognised from surface exposures of shell midden and red-slipped pottery, some with dentate stamping, at the west end of Vutuna beach (Figure 78). Because of time constraints, only 3 sq. $\mathrm{m}$ of the site was excavated $-2 \mathrm{~m}$ from a shell midden adjacent to Tokelau stream at the base of a natural volcanic-boulder mound (Figures 79-80), and a single unit called Test Pit 1, $60 \mathrm{~m}$ southeast of the midden. The analysis of the excavated materials and preliminary interpretation of the site were published by Clark et al. (2001:142), who concluded that: 'Although the site might extend to 3000 square metres, and bearing in mind the very small 


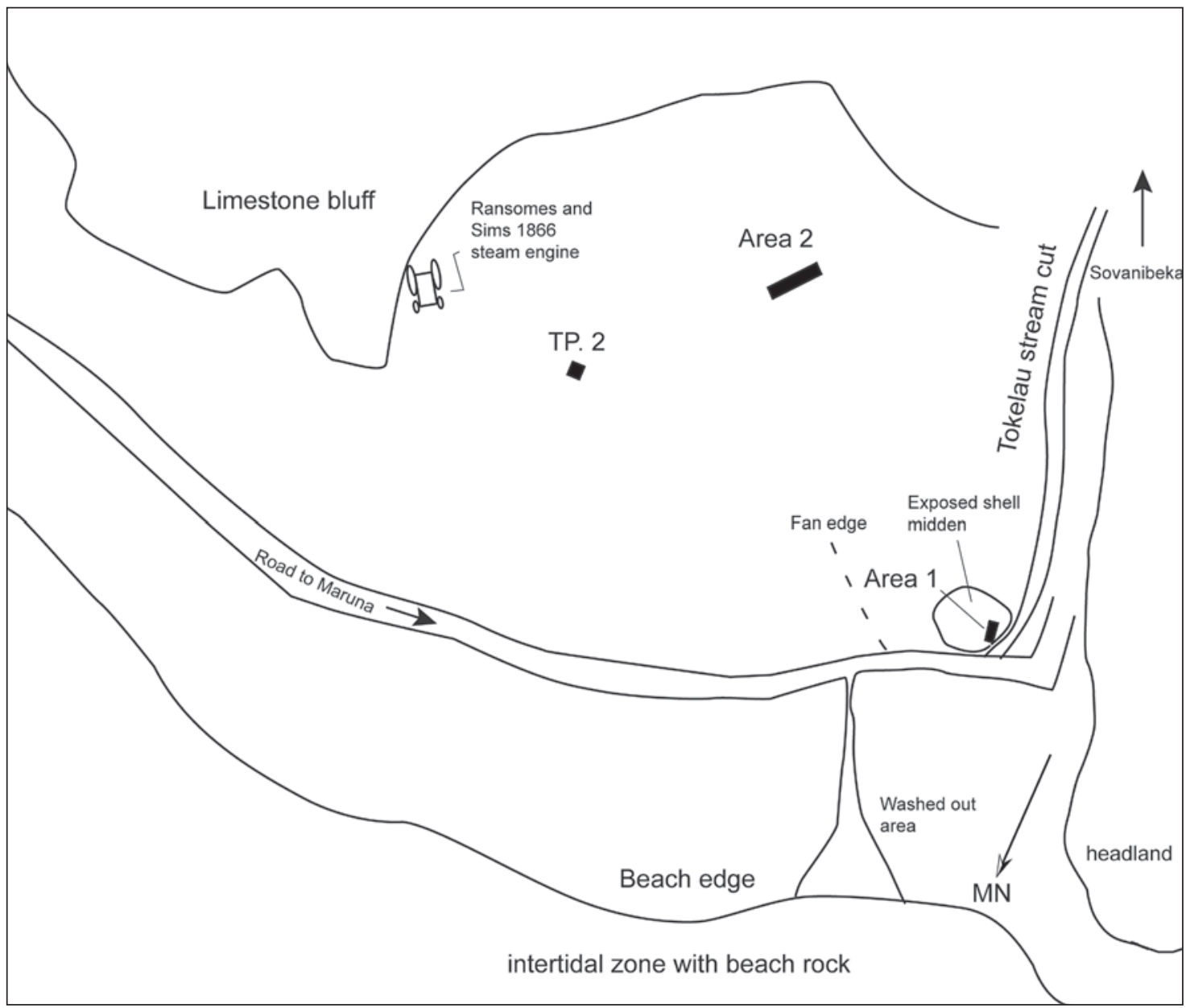

Figure 79. Votua, plan view of 1996 and 2000 excavations. Compass and tape map by G. Hope.

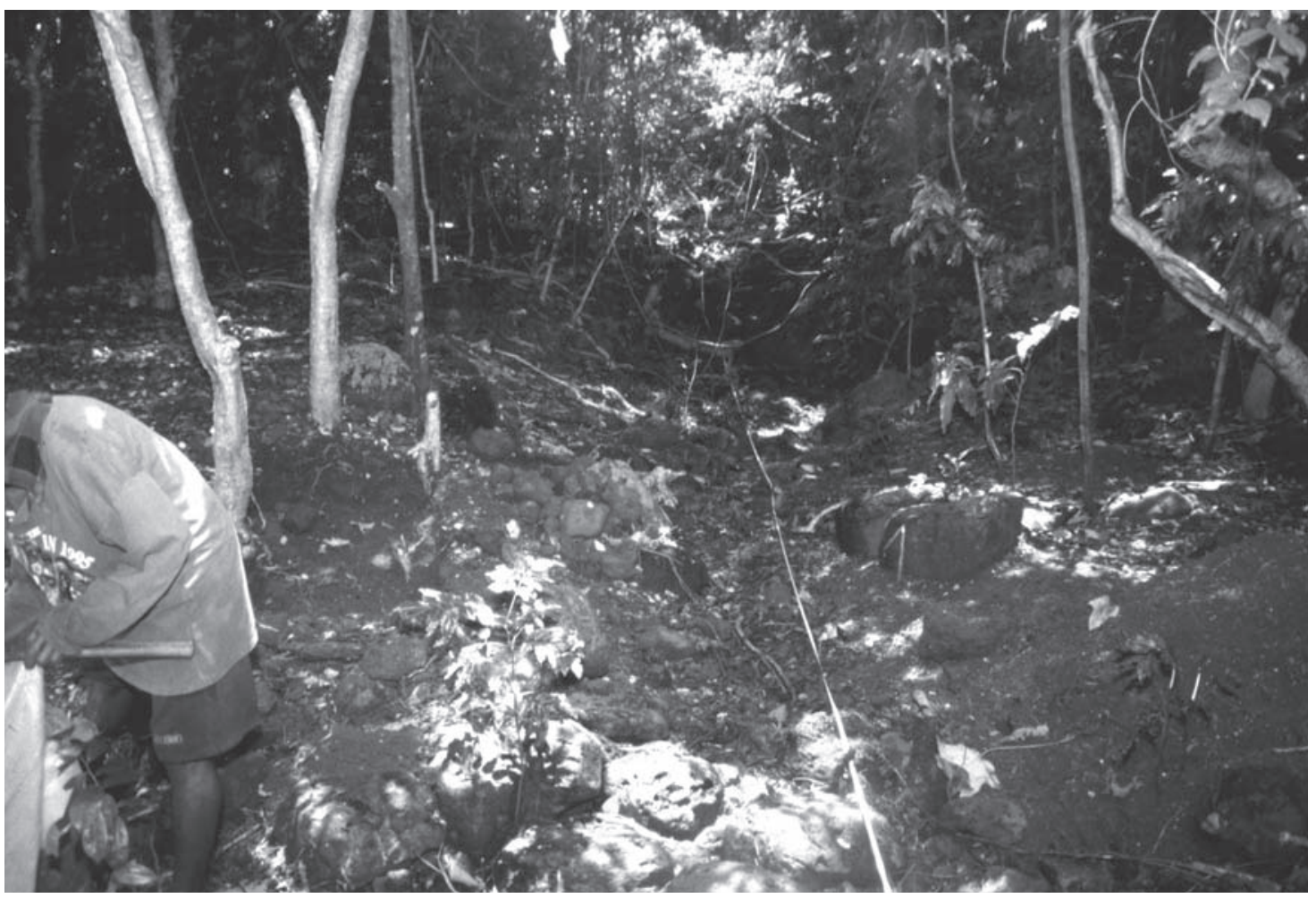

Figure 80. South view up the Tokelau stream bed. The Area 1 shell midden is behind the figure in the foreground. 
size of the excavated sample, Votua can be considered nonetheless as an example of the mobile or encampment mode of Lapita settlement primarily sustained by marine and terrestrial wild foods, rather than the hamlet or village mode which is represented elsewhere.'

The conclusion was necessarily qualified due to the small size of the 1996 excavations, the dry sieving of the clayey soils, which can lead to the recovery of unrepresentative samples of material culture, and the restricted understanding of the site's extent and its past environmental setting. Clearly, better information from more detailed investigations could significantly change the interpretation of the Votua site, and thus of the variation in settlement pattern suggested for Lapita settlement in the Fiji Islands, for which Votua offered some preliminary evidence.

New work at the Votua site was undertaken in December 2000 during a research visit to Vanuabalavu organised by Professor Patrick Nunn (USP). The research aims were threefold. First, to determine the site limits with greater accuracy. In 1996, plain pottery had been identified some $250 \mathrm{~m}$ from Vutuna stream, but the main Lapita occupation zone at Votua was thought to cover only about 1000 to 3000 sq. $\mathrm{m}$ of the small sand plain to the east of Tokelau stream. Was this estimate reliable or did Votua extend over a much larger area? Second, would water sieving of the Votua deposits increase the faunal and artefactual remains to a point where the proposed 'mobile or encampment mode' of settlement might be challenged? Last, what was the environmental setting of the Lapita occupation at Votua?

The Votua site is located at the west end of Vutuna Beach on an indented limestone-backed sand plain, approximately 1.5-2.0 m above sea level, adjacent to Tokelau stream - a small and impermanent water course (Figures 79-80). The stream follows the boundary between the late Pleistocene volcanics and older limestone deposits and a mound of rounded basalt and limestone boulders lies immediately east of the stream, with the base of the mound on its seaward edge defined by the plantation road to Maruna. The sand plain is bordered in the east by limestone ridges and outcrops and in the south and east by a slope deposit containing soil, limestone and weathered volcanic boulders. The Vutuna sand plain was planted in coconut palms (Cocos nucifera) by at least 1882 (G. Ward, pers. comm., ANU), when it was owned by the Ryder brothers who used about 300 labourers from the Solomon Islands, Vanuatu, Tokelau, Tuvalu and Kiribati to work their plantations (Gordon Cumming 1885:333).

A trench $1 \mathrm{~m} \times 4 \mathrm{~m}$ called Area 2 was laid out beside the 1996 Test Pit 1 excavation (Figure 79). Area 2 was about $75 \mathrm{~m}$ from the beach edge and the south square of Area 2 was placed near the top of a small rise, with other excavation squares down-slope. A single $1 \mathrm{~m} \times 1 \mathrm{~m}$ square called Test Pit 2 was placed 19 m northeast of Area 2 and near a limestone cleft containing the remains of an 1866 'Ransomes and Sims' portable steam engine. The sand plain was tested with shovel holes and a soil/sand auger to identify the extent of the Lapita cultural deposits.

Area 2 and Test Pit 2 excavations were by $10 \mathrm{~cm}$ spit using a trowel. In contrast to the 1996 excavations, all the excavated deposits were water sieved through $3 \mathrm{~mm}$ mesh using water pumped from the fringing reef, or directly in the sea itself when the water pump broke down. Pot sherds and marine shell were bagged and taken to Maruna and recorded before the majority of plain sherds and shells were dumped at the garden edge at the back of the Maruna sand plain. Rim, neck and carinated sherds were retained and voucher specimens of all shell taxa collected for identification at the ANU. Field processing of the ceramics and particularly the shellfish was necessary because of weight limitations on the plane flight from Vanuabalavu to Viti Levu. As the total marine-shell weight was over $50 \mathrm{~kg}$ for each $1 \mathrm{~m}$ square excavated at Area 2, we were obliged to identify, count and weigh marine-shellfish remains in the field. The loss of information resulting from this procedure was partially offset by the presence of complete shellfish samples analysed from the 1996 excavations, particularly Test Pit 1, which was immediately beside the 
Area 2 trench. Other cultural remains, such as fauna, charcoal, and artefacts of stone, coral and shell, represent complete samples that were bagged separately and returned to the ANU.

\section{Votua Area 2}

The stratigraphy of Area 2 is similar to that recorded from Test Pit 1 in 1996, where three layers were identified, but the more recent work added extra detail to the original layer descriptions (Figure 81).

Layer 1: Varied in depth from $22 \mathrm{~cm}$ to $30 \mathrm{~cm}$. It consisted of a black to very darkbrown clay silt (10YR 2/1-2/2, $\mathrm{pH}=8.5-9.0)$, with tree roots and dispersed and fragmented remains of marine shells, small flakes of silicious material and patches of charcoal.

Layer 2: The main cultural layer. It varied from hard-packed brown to dark-brown silty clay containing sand (10YR 2/2 to 10YR 4/3, pH=8.0-9.5). Within Layer 2 were thin lenses of weathered ash varying in colour from purple/brown to yellow/white. At $42 \mathrm{~cm}$ depth there was a thin discontinuous lens of clean beach sand. From $40 \mathrm{~cm}$ to $60 \mathrm{~cm}$ the deposit consisted of a compact shell midden dominated by Anadara and Gafrarium.

The base of the cultural deposit was reached at $60 \mathrm{~cm}$, except where small amounts of cultural material were deposited in small depressions penetrating Layer 3. At the bottom of the shell midden were valves of a large oyster (Crassostrea sp.). Large and small basalt rocks occurred throughout Layer 2 and while some appeared to be slope or human derived, others were clearly in original position, as shown by the position of ash lenses abutting some large rocks. This layer yielded a variety of shell artefacts, including ornaments, a fish hook, stone flakes, an adze, coral abraders and remains of fish, bird and turtle.

Layer 3: A brown compact clay (10YR 4/3, pH=8.0-8.5) with no charcoal, marine shell, or any other cultural remains. It was tested down to $120 \mathrm{~cm}$ depth with no change in the nature of the matrix recorded.

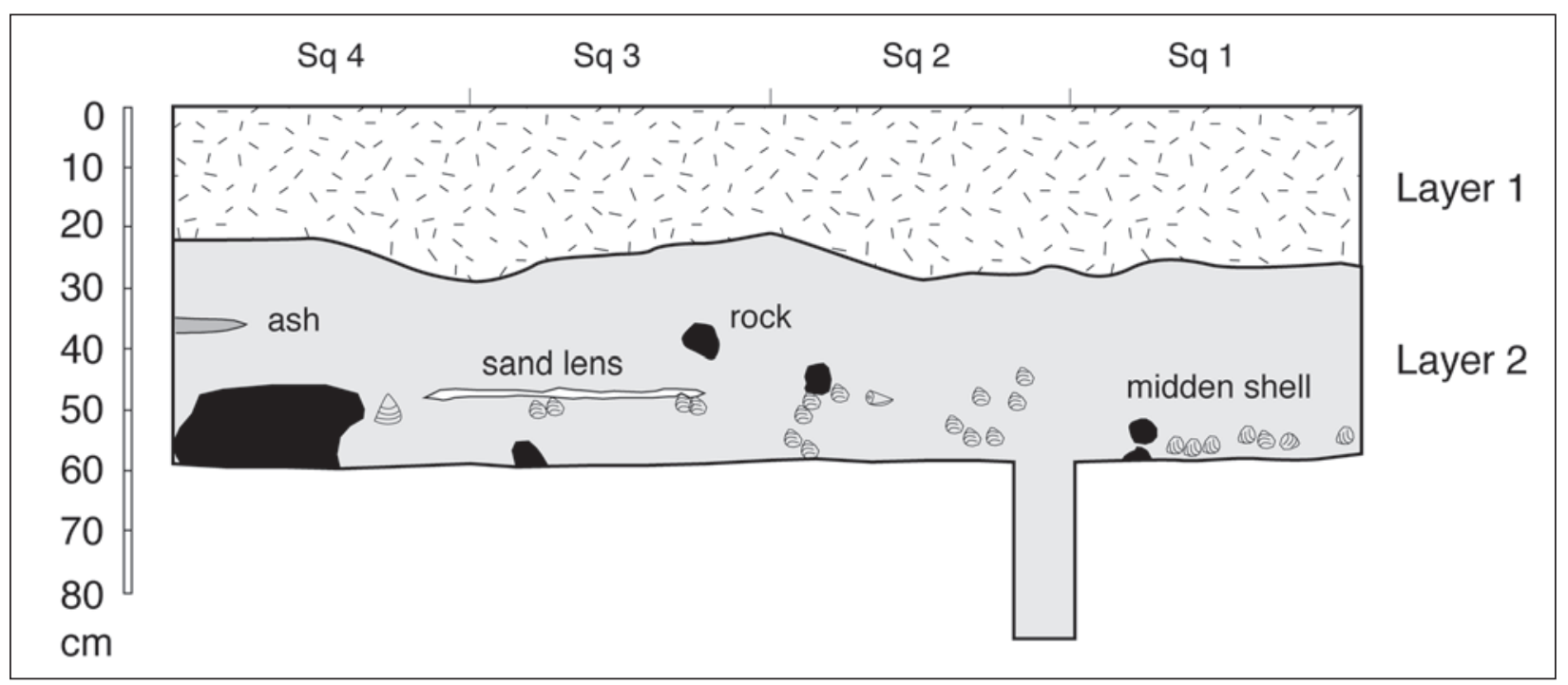

Figure 81. Votua, Area 2 stratigraphy (see Clark et al. 2001 for details of Area 1).

\section{Votua Test Pit 2}

The upper $20-30 \mathrm{~cm}$ of Test Pit 2 contained small marine bivalves fragmented in a reddishbrown sandy sediment with limestone and basalt rubble. Below this, shell and pottery fragments and pottery were more abundant, but the ceramic sherds were small, most less than $3 \mathrm{~cm}^{2}$. The 
sand lens noted in Area 2 was also present in Test Pit 2 at a depth of ca. $35 \mathrm{~cm}$ and sterile cultural deposits of a dark-brown clay were reached at 50-60 cm depth. It seems likely that material from Test Pit 2 represents a disturbed deposit derived from the main deposit of prehistoric material on the old beach edge, as there was significantly less shell midden and pottery in Test Pit 2 than in Area 2 and it was significantly more fragmented, and it contained little bone or charcoal and only a few stone flakes.

The ash lenses in Layer 2 were usually about $1-3 \mathrm{~cm}$ thick and were present in patches over the entire area of Area 2, especially in the southern part towards the top of the small rise. It was difficult to separate out defined hearth zones due to the thinness of the ash deposits and the evidence for multiple small cooking fires in Area 2. Beside a few large basalt rocks a stratigraphic sequence of ash lenses was identified, but no stone-edged hearths or defined fire places were evident. Dug into the surface of Layer 3 were several round depressions that might have been stake or post holes. However, these were generally shallow, only $10-15 \mathrm{~cm}$ deep, and could conceivably result from the removal of rocks or be the base of shallow fire pits.

\section{Site extent}

Renewed investigations at Votua, including excavations, test pitting, augering and walk-over survey of the area, suggest the following. First, the main band of concentrated cultural deposits appears to be closely associated with the slope that marks the western and southern edge of the sand plain. This feature probably corresponds to the edge of an old shoreline that was available for human settlement during, or slightly after, a drop in sea level. Although the site might have extended further east beyond the limestone point containing the portable steam engine (Figure 79), surface collection of sherds from areas to the east of the point included spot-impressed and other late styles of Fijian pottery. This suggests Votua is probably around 1000 sq. $\mathrm{m}$ in extent and might occupy only $500 \mathrm{sq}$. $\mathrm{m}$ if the primary band of cultural debris is relatively narrow and restricted to the confines of the old shoreline, as suggested by the Test Pit 2 excavation.

Second, the restriction of settlement to the western end of Vutuna appears to be tied to the presence of a deeply indented bay whose limits are shown by the contour of the old shoreline. The bay was subsequently infilled by slope and reef-derived deposits. The small embayment would have been sheltered from prevailing southeast trade winds and appears to have fostered the kind of protected intertidal environment that supported concentrations of Anadara and Gafrarium bivalves. The sheltered position also supported mangroves, which is evidenced by the round cross-sections found on the back of Crassostrea sp. shells as a result of their attachment to aerial mangrove roots. In addition to the intermittent freshwater stream and number of nearby small springs along the limestone cliffs east of Votua, the site is at the base of a natural access route to Maruna and also to the interior of the island. Jasper flakes, calcareous-tempered pottery and a piece of dentate-stamped pottery were recovered from beach-rolled deposits at Maruna, and a dentate-stamped sherd was found at Sovanibeka (see below). This suggests that Lapita people were travelling to areas other than the coastal zone of Mago Island, perhaps for the purposes of hunting terrestrial birds and gardening.

Finally, the water sieving of deposits did result in the recovery of a larger set of artefacts and fauna than was found in the 1996 excavations and these are described elsewhere in this volume. Compact shell midden and ash from cooking fires mixed with pottery and other artefacts suggest that Area 2 was a multipurpose cooking/consumption/refuse dumping area. It is sufficient to note here that evidence for artefact manufacture, other than siliceous stone flakes, while present, is not particularly abundant or diverse, while the faunal deposits appear to represent a relatively brief period of activity, consistent with the earlier interpretation of the site. The reduction in 
the estimate of site size is also consistent with the 'mobile or encampment mode' of settlement proposed by Clark et al. (2001). Votua is one of the few single-phase Lapita sites known in the Fiji Islands, and unlike Level 1 of Sigatoka, it has well-preserved fauna and artefactual remains. Further work at this site is required to identify whether there is any evidence for substantial structures, perhaps of houses, above or in front of the old shoreline, or whether formal structures were not, apparently, part of the colonising strategy employed during the late-Lapita occupation of the Lau Islands.

\section{Sovanibeka, Mago Island}

A complex of caves and chambers was located in the makatea cliff at ca. $40 \mathrm{~m}$ altitude and about $300 \mathrm{~m}$ southwest of Vutuna Beach by Mr Mani Prasad. The complex, called Sovanibeka by S. Matararaba in 1996, appears to be one of those explored and briefly described by Sawyer and Andrews (1901), who did not record the presence of prehistoric remains. The cave complex includes substantial underground passages and an eroded former chamber now accessible through two sides, with a further high-level entrance allowing natural light to enter (Figure 82). The chamber is about $10 \mathrm{~m}$ long and $7 \mathrm{~m}$ wide, with a gently sloping dry-earth floor. On its southeast side is a raised shelf $5 \mathrm{~m}$ in length and $2 \mathrm{~m}$ broad which has scatters of marine shellfish and charcoal. Fine, grey, silty sands on this shelf extend to about $40 \mathrm{~cm}$ depth and partly derive from the droppings of a resident group of white-rumped swiftlets (Collocalia spodiopygia).

The chamber was investigated in 1996 (Clark and Hope 1997), and was subsequently visited briefly in 2000 during the second season of excavations at Votua, but material from test pits was collected during the first visit only. The chamber was initially targeted because it seemed a likely place in which subfossil remains of birds and other fauna might be found, and the discovery of pottery and midden material was therefore unexpected.

\section{Test Pits}

A small $30 \mathrm{~cm} \times 30 \mathrm{~cm}$ test pit called Test Pit 1 was dug in the middle of the main open area (Figure 82). The top $20 \mathrm{~cm}$ of the deposit contained marine shells, charcoal, plain pottery, firecracked rock, and at $20 \mathrm{~cm}$ depth, large fragments of turtle bone. Below this the deposit was composed of a light reddish-brown fine silt containing shell and rock fragments and pot sherds.

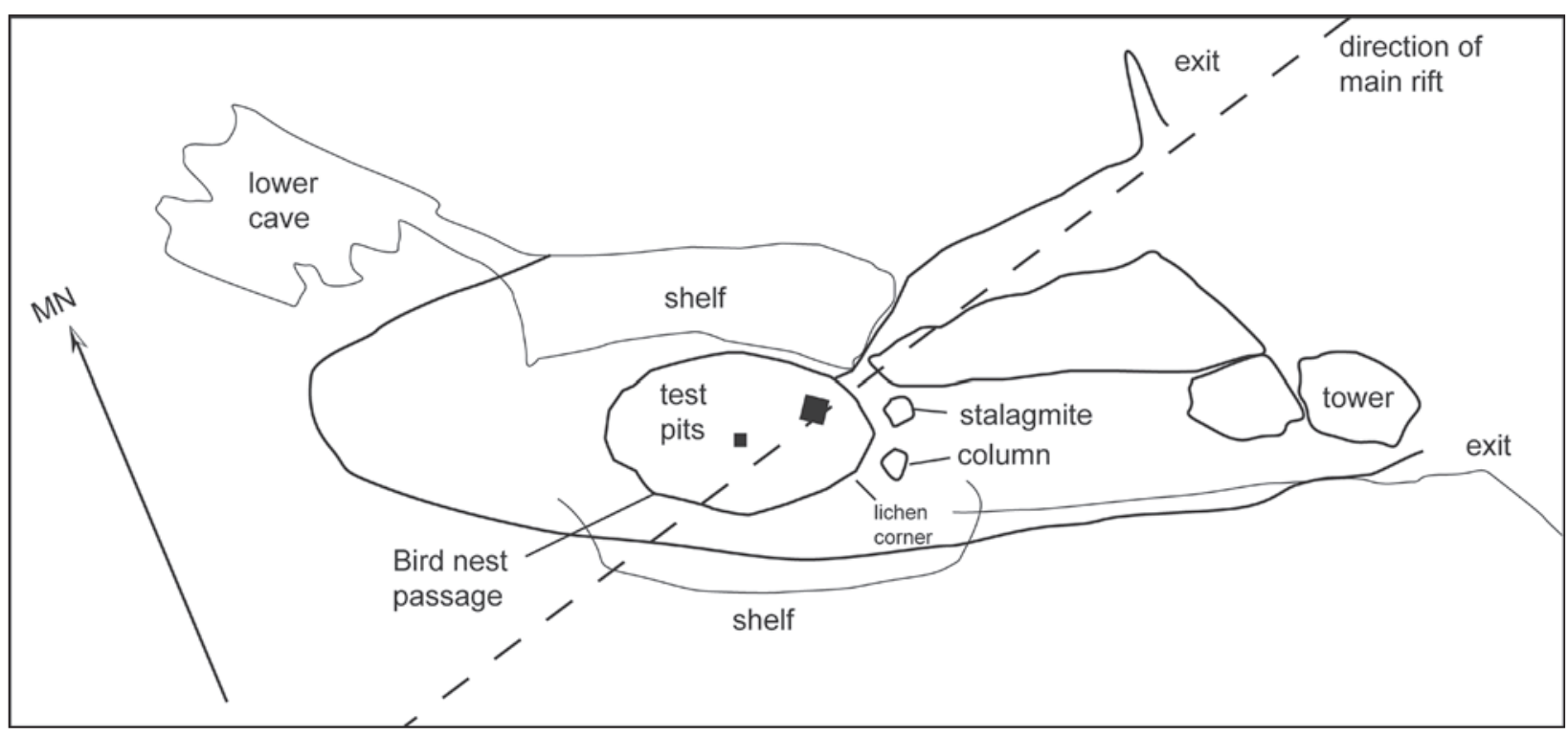

Figure 82. Sovanibeka rock shelter and location of test excavations. 
Mixed through the upper and lower deposits to a depth of ca. $50 \mathrm{~cm}$ was a large amount of rat bone.

A second excavation, called Test Pit 2, was made to further sample the floor deposits. This was a $50 \mathrm{~cm} \times 50 \mathrm{~cm}$ square excavated on the floor of the cave, approximately $2 \mathrm{~m}$ from the northern wall (Figure 82). The second test pit confirmed the stratigraphic picture obtained from Test Pit 1, but made important pottery finds. These consisted of a sherd decorated with an intersecting line of dentate stamping, at approximately $40-50 \mathrm{~cm}$ depth, and above it a rimneck sherd decorated with oval rim notching and cross-hatch paddle relief, and body sherds marked by curvilinear relief, also called 'wavy' relief.

\section{Test Pit 2 stratigraphy}

0-10 cm: Brown clayey silt with abundant leaf and wood debris and rat bones.

10-42 cm: Grey ashy clayey silts with numerous pieces of limestone and some basalt rocks. Scattered lenses of ash and marine shell were abundant from about $20-40 \mathrm{~cm}$ depth, with pottery frequent at $30-40 \mathrm{~cm}$ depth, including a few large sherds, some of which were marked with different kinds of paddle relief. Rat bone became sparser as depth increased, while land snails became more abundant.

42-60 cm: Reddish-brown clay with many land-snail shells, but very sparse marine shell, pot sherds, charcoal or rat bone below $55 \mathrm{~cm}$.

The limited data from Test Pits 1 and 2 indicates human use of Sovanibeka was infrequent and perhaps non-intensive, although the presence of turtle bone could suggest ceremonial or ritual activity in the small concealed chamber space. The loose and friable chamber deposits of Sovanibeka have been heavily disturbed and the small size of the test-pit excavations only hints at the range of prehistoric activities that might have been carried out in the chamber. Pottery, midden shell and small amounts of fish bone show that the location was used for cooking and food consumption, but a better understanding of the site requires further archaeological investigations. 


\section{References}

Best, S. 1984. Lakeba: The prehistory of a Fijian Island. Unpublished PhD thesis, Department of Anthropology, University of Auckland.

Best, S. 2002. Lapita: A view from the east. New Zealand Archaeological Association Monograph 24.

Burley, D.V. 2005. Mid-sequence archaeology at the Sigatoka Sand Dunes with interpretive implications for Fijian and oceanic culture history. Asian Perspectives 44: 320-348.

Clark, G. and Hope, G. 1997. Archaeological and palaeoenvironmental investigations in northern Lau (Mago, Yacata-Kaibu and Vatuvara). Unpublished report to the Fiji Museum, Suva.

Clark, G., Anderson, A. and Matararaba, S. 2001. The Lapita site at Votua, northern Lau Islands, Fiji. Archaeology in Oceania 36: 134-145.

Clark, G. and Murray, T. 2006. Decay characteristics of the eastern Lapita design system. Archaeology in Oceania 41: 107-117.

Curtis, G.H. 1951. Appendix I. Petrography of pottery. In: Gifford, E.W. Archaeological excavations in Fiji, pp. 239-241. University of California Anthropological Records 13: 189-288.

Davidson, J., Hinds, E., Holdaway, S. and Leach, F. 1990. The Lapita site of Natunuku, Fiji. New Zealand Journal of Archaeology 12: 121-155.

Davidson, J. and Leach, F. 1993. The chronology of the Natunuku site, Fiji. New Zealand Journal of Archaeology 15: 99-105.

DeGusta, D. 1999. Fijian cannibalism: Osteological evidence from Navatu. American Journal of Physical Anthropology 110: 215-241.

Derrick, R. 1951. The Fiji Islands: A geographical handbook. Government Printing Office, Suva.

Dickinson, W.R. 1971. Petrography of some sand tempers in prehistoric pottery from Viti Levu, Fiji. Final report No. 2. Records of the Fiji Museum 1: 108-121.

Fowler, H.W. 1955. Archaeological fishbones collected by E.W. Gifford in Fiji. Bernice P. Bishop Museum Bulletin 214.

Frazer, R.M. 1963. A social and economic history of Ra Province. Transactions and Proceedings of the Fiji Society 9: 93-112.

Geraghty, P.A. 1983. The history of the Fijian languages. Oceanic Linguistics Special Publication No. 19. University of Hawaii Press, Honolulu.

Gifford, E.W. 1951. Archaeological excavations in Fiji. University of California Anthropological Records 13: 189-288.

Gifford, E.W. 1952a. Tribes of Viti Levu and their origin places. University of California Press, Berkeley.

Gifford, E.W. 1952b. A carbon-14 date from Fiji. Journal of the Polynesian Society 61: 327.

Gifford, E.W. 1955. Six Fijian radiocarbon dates. Journal of the Polynesian Society 64: 240.

Gordon Cumming, C.F. 1885. At home in Fiji. William Blackwood and Sons, Edinburgh and London.

Green, R.C. 1963. A suggested revision of the Fiji sequence. Journal of the Polynesian Society 72 : 235-253.

Green, R.C. 1974. Sites with Lapita pottery: Importing and voyaging. Mankind 9: 253-259.

Hunt, T.L. 1980. Toward Fiji's past; archaeological research on southwestern Viti Levu. Unpublished MA thesis, University of Auckland.

Key, C.A. n.d. The geological structure at Natunuku. Unpublished manuscript in possession of the authors. Department of Archaeology and Natural History, Australian National University.

Kirch, P.V. and Hunt, T.L. 1988. The spatial and temporal boundaries of Lapita. In: Kirch, P.V. and Hunt, T.L. (eds), Archaeology of the Lapita cultural complex: A critical review, pp. 9-32. Thomas Burke Memorial Washington State Museum Research Report No. 5. The Burke Museum, Seattle.

Kuhlken, R. and Crosby, A. 1999. Agricultural terracing at Nakauvadra, Viti Levu: A late prehistoric irrigated agrosystem in Fiji. Asian Perspectives 38: 62-89.

Ladd, H.S. and Hoffmeister, J.E. 1945. Geology of Lau, Fiji. Bernice P. Bishop Museum Bulletin 181.

Mead, S., Birks, L., Birks, H. and Shaw, E. 1973. The Lapita pottery style of Fiji and its associations. Journal of the Polynesian Society Memoir 38: 1-98. 
Nunn, P.D. 1990. Coastal processes and landforms of Fiji: Their bearing on Holocene sea level changes in the south and west Pacific. Journal of Coastal Research 6: 279-310.

Palmer, J.B. 1968. Recent results from the Sigatoka archaeological program. In: Yawata, I. and Sinoto, Y.H. (eds), Prehistoric culture in Oceania, pp. 19-27. B.P. Bishop Museum Press, Honolulu.

Parry, J. 1987. The Sigatoka valley - pathways into prehistory. Fiji Museum Bulletin No. 9. The Fiji Museum, Suva.

Parry, J.T. 1997. The north coast of Viti Levu Ba to Ra. Air photo archaeology and ethnohistory. Bulletin of the Fiji Museum No. 10.

Rodda, P. 1976. Geology of northern and central Viti Levu. Fiji Mineral Resources Division Bulletin 3.

Sawyer, B. and Andrews, E.C. 1901. Notes on the caves of Fiji, with special reference to Lau. Proceedings of the Linnean Society of New South Wales 29: 91-106.

Seeley, J.B. and Searle, E.J. 1970. Geology of the Rakiraki district, Viti Levu, Fiji. New Zealand Journal of Geology and Geophysics 13: 52-71.

Shaw, E. 1967. A reanalysis of pottery from Navatu and Vuda, Fiji. Unpublished MA thesis, Department of Anthropology, University of Auckland.

Spriggs, M. 1990. Dating Lapita: Another view. In: Spriggs, M. (ed), Lapita design, form and composition, pp. 83-122. Occasional Papers in Prehistory, No. 20. Department of Prehistory, Australian National University, Canberra.

Wahome, E.W. 1995. Ceramic and prehistoric exchange in the Admiralty Islands, Papua New Guinea. Unpublished PhD thesis, Australian National University.

Woodhall, D. 1985. Geology of the Lau Ridge. In: Scholl, D.W. and Vallier, T.L. (eds), Geology and offshore resources of Pacific Island arcs - Tonga region. Circum-Pacific Council for Energy and Mineral Resources Earth Science Series, Volume 2, pp. 351-378. Houston, Texas. 